\title{
Using stable isotopes and major ions to identify recharge characteristics of the Alpine groundwater-flow dominated Triglavska Bistrica River
}

\section{Uporaba stabilnih izotopov in glavnih ionov za oceno napajalnih značilnosti alpskega rečnega toka Triglavske Bistrice pod vplivom podzemne vode}

\author{
Luka SERIANZ ${ }^{1,2}$, Sonja CERAR ${ }^{1} \&$ Polona VREČA ${ }^{3}$
}

${ }^{1}$ Geological Survey of Slovenia, Dimičeva ulica 14, SI-Ljubljana, Slovenia; e-mail: luka.serianz@geo-zs.si ${ }^{2}$ Faculty of Civil and Geodetic Engineering, University of Ljubljana, Jamova cesta 2, SI-Ljubljana, Slovenia; ${ }^{3}$ Department of Environmental Sciences, Jožef Stefan Institute, Jamova cesta 39, SI-1000, Ljubljana, Slovenia.

Prejeto / Received 5. 10. 2021; Sprejeto / Accepted 7. 12. 2021; Objavljeno na spletu / Published online 28. 12.2021

Key words: groundwater, oxygen and hydrogen isotopes, hydrogeochemistry, recharge area, Alpine aquifer, Slovenia

Ključne besede: podzemna voda, kisikovi in vodikovi izotopi, hidrogeokemija, napajalno območje, alpski vodonosnik, Slovenija

\begin{abstract}
Triglavska Bistrica is a typical Alpine river in the north-western part of Slovenia. Its recharge area includes some of the highest peaks in the Julian Alps. The hydrogeological conditions and flow of the river depend largely on groundwater exchange between the karstified aquifer in the carbonate rocks and the intergranular aquifer in the glaciofluvial deposits. The average volume of the river flow is up to several $\mathrm{m}^{3} / \mathrm{s}$. In this study, water samples from different locations along the river were analysed for stable isotope ratios of oxygen and hydrogen, major ions, and concentration of tritium activity. The correlation of major ions suggests that the recharge area consists of both limestone and dolomite rocks. The $\delta^{18} \mathrm{O}$ and $\delta^{2} \mathrm{H}$ values decrease downstream, implying that the average recharge elevation increases. At the downstream sampling site V-5, located approx. $300 \mathrm{~m}$ upstream from the confluence of the Sava Dolinka River, the calculated mean recharge altitude is estimated to be $1,996 \mathrm{~m}$.
\end{abstract}

\section{Izvleček}

Triglavska Bistrica je tipična alpska reka, ki se nahaja v severozahodnem delu Slovenije. Njeno napajalno zaledje pokriva nekaj najvišjih vrhov v Julijskih Alpah. Hidrogeološke razmere in rečni tok sta v veliki meri odvisna od izmenjave podzemne vode med kraško-razpoklinskim vodonosnikom v karbonatnih kamninah in medzrnskim vodonosnikom v glaciofluvialnih sedimentih. Povprečen pretok reke v spodnjem toku je ocenjen na nekaj $\mathrm{m}^{3} / \mathrm{s}$. V tej študiji so bila določena razmerja stabilnih izotopov kisika in vodika, koncentracije glavnih ionov in koncentracija aktivnosti tritija v vzorcih vode na različnih lokacijah nizvodno od izvira Triglavske Bistrice. Na osnovi korelacije osnovnih ionov je možno sklepati, da je napajalno zaledje sestavljeno tako iz apnenca kot tudi dolomita. Vrednosti $\delta^{18} \mathrm{O}$ in $\delta^{2} \mathrm{H}$ upadajo dolvodno od izvirnega območja, kar pomeni, da povprečna nadmorska višina napajanja narašča. Na dolvodnem merilnem mestu V-5, ki se nahaja približno 300 m nad sotočjem s Savo Dolinko, znaša izračunana povprečna nadmorska višina napajanja $1.996 \mathrm{~m}$.

\section{Introduction}

Triglavska Bistrica is a small Slovenian river flowing in the Vrata glacial valley and surrounded by the highest peaks in Slovenia. Its special characteristics are recognizable by the different topographical features of the watershed, which stretches from the highest Slovenian mountain Triglav $(2,864 \mathrm{~m}$ a.s.l) to the confluence with the Sava Dolinka River at an altitude of about
$640 \mathrm{~m}$ a.s.l. The length of the constant the river flow is about $8 \mathrm{~km}$, and on this stretch the riverbed drops by about $250 \mathrm{~m}$. Under diverse topographical conditions specific hydrogeological settings are formed, which are typical for alpine river valleys. A river is enriched either with groundwater from the riparian zone or by direct inflow from the rock in the riverbed, as is the case with other alpine rivers in Slovenia (e.g. 
Brenčič \& Vreča, 2016; Torkar et al., 2016). At the same time, water from the river can infiltrate the banks and surrounding aquifers. These conditions change temporally (seasonally) and spatially (lithology, geomorphological processes, etc.). Hydrogeochemical methods are among the most useful approaches to identify such conditions and determine other physiochemical processes. In carbonate reservoirs, the main chemical parameters describing carbonate equilibrium in groundwater are calcium $\left(\mathrm{Ca}^{2+}\right)$, magnesium $\left(\mathrm{Mg}^{2+}\right)$, their molar ratio $\left(\mathrm{Ca}^{2+} / \mathrm{Mg}^{2+}\right)$, and hydrogen carbonate $\left(\mathrm{HCO}_{3}{ }^{-}\right)$. In addition to chemical parameters, stable isotope ratios of oxygen and hydrogen (expressed as $\delta^{18} \mathrm{O}$ and $\delta^{2} \mathrm{H}$ ) in water can also provide information on recharge areas (Clark and Fritz, 1997), while tritium activity concentration $\left({ }^{3} \mathrm{H}\right)$ can provide information on the average residence time of groundwater. A combination of chemical and isotope data has been widely used for hydrogeological research of alpine water streams (Carey \& Quinton, 2005; Thiébauda et al., 2010; Shamsi et al., 2019), and the same techniques have been applied also in Slovenia (Kanduč et al., 2012; Torkar et al., 2016).

The Triglavska Bistrica watershed consists of massive limestone and dolomite rocks with fractures and karstic porosity. It is therefore very likely that dissolution of carbonate minerals is the most important hydrogeochemical process affecting the chemical components of natural water flow. There is very little data on the hydrogeochemistry of the groundwater in the monitoring area, but several chemical analyses are available for a spring near the Peričnik waterfall, which was included in the study of the hydrogeochemistry of alpine springs from northern Slovenia (Kanduč et al., 2012). These studies suggest that the water of the alpine springs is dominated by $\mathrm{HCO}_{3}{ }^{-}, \mathrm{Ca}^{2+}$ and $\mathrm{Mg}^{2+}$ ions and that most of the springs were near equilibrium in terms of calcite. These results can be confirmed by recent hydrogeochemical studies in similar environments (Mezga, 2014; Torkar et al., 2016; Serianz et al., 2020b).

It is commonly observed that precipitation gradually becomes depleted in ${ }^{18} \mathrm{O}$ and ${ }^{2} \mathrm{H}$ isotopes as altitude increases (Dansgaard, 1964). This phenomenon is commonly referred to as the "altitude effect" and results primarily from the cooling of air masses as they ascend a mountain range, accompanied by the dissipation of excess moisture (Gonfiantini et al., 2001; Kern et al., $2020)$. In the case of $\delta^{18} \mathrm{O}$-precipitation, the global average gradient with altitude is $-2.8 \% / \mathrm{km}$, and ranges from -1.7 to $-5.0 \% / \mathrm{km}$; the European average is $-2.1 \% / \mathrm{km}$ (Poage and Chamberlain, 2001). On Slovenian territory, for example, the altitude effect on precipitation ranges from $-0.2 \%$ to $-0.3 \%$ o $\delta^{18} \mathrm{O} / 100 \mathrm{~m}$ (Vreča et al., 2006; Brenčič and Polting, 2008). For Croatia and Slovenia combined, these values range from $-0.37 \%$ to $-0.26 \% \delta^{18} \mathrm{O} / 100 \mathrm{~m}$ (Horvatinčić et al., 2005). For other countries, such as Austria, the altitude effect is estimated to be $-0.21 \% \delta^{18} \mathrm{O} / 100 \mathrm{~m}$ (Kralik et al., 2003) and the value for Italy is estimated at roughly $0.2 \% \delta^{18} \mathrm{O} / 100 \mathrm{~m}$ (Longinelli and Selmo, 2003). Based on the fact that the isotopic composition in precipitation is reflected in the isotopic composition of groundwater, Mezga et al. (2013) calculated three elevation effects for groundwater following different patterns of precipitation intensity, ranging from $-0.25 \% \delta^{18} \mathrm{O} / 100 \mathrm{~m}$ for the Alps and the coastal region to $0.33 \% \delta^{18} \mathrm{O} / 100 \mathrm{~m}$ for the Bela Krajina region (Cerar et al., 2018). Recent studies in the Adriatic-Pannonian region indicate an empirical isotopic altitude effect in modern precipitation for $\delta^{18} \mathrm{O}$, which is $-1.2 \% / \mathrm{km}$ and $-7.9 \% / \mathrm{km}$ for the $\delta^{2} \mathrm{H}$ (Kern et al., 2020).

The objective of this research is to identify the source, type, and amount of the different water components of the Triglavska Bistrica River recharge, to describe their spatial variations using hydrochemical, isotopic, and hydrogeological methods, and to estimate the mean recharge altitude of the Triglavska Bistrica River.

\section{Study area settings}

\section{General settings}

The Triglavska Bistrica River courses through the heart of the Julian Alps in the north-western part of Slovenia and flows on through the Vrata Valley. In Mojstrana, a small settlement at the end of the valley, Triglavska Bistrica flows into the Sava Dolinka River, which joins the Sava Bohinjka River to form the Sava River, the largest tributary of the Danube by water volume. Triglavska Bistrica is a typical Alpine River, which flows in the Vrata glacial valley. It flows under Triglav North, the highest mountain in the country. The largest stream flowing into the river is the Peričnik. The Triglavska Bistrica flows into the Sava Dolinka River about $10 \mathrm{~km}$ downstream, with a gradient of about $400 \mathrm{~m}$, and is surrounded by mountains with the greatest number of peaks above $2,500 \mathrm{~m}$ a.s.l. in its catchment area. The water percolates out of extensive scree at the foot of the wall (Smolar-Žvanut et al., 2005). On its way to the Sava Dolinka, the Triglavska Bistrica 


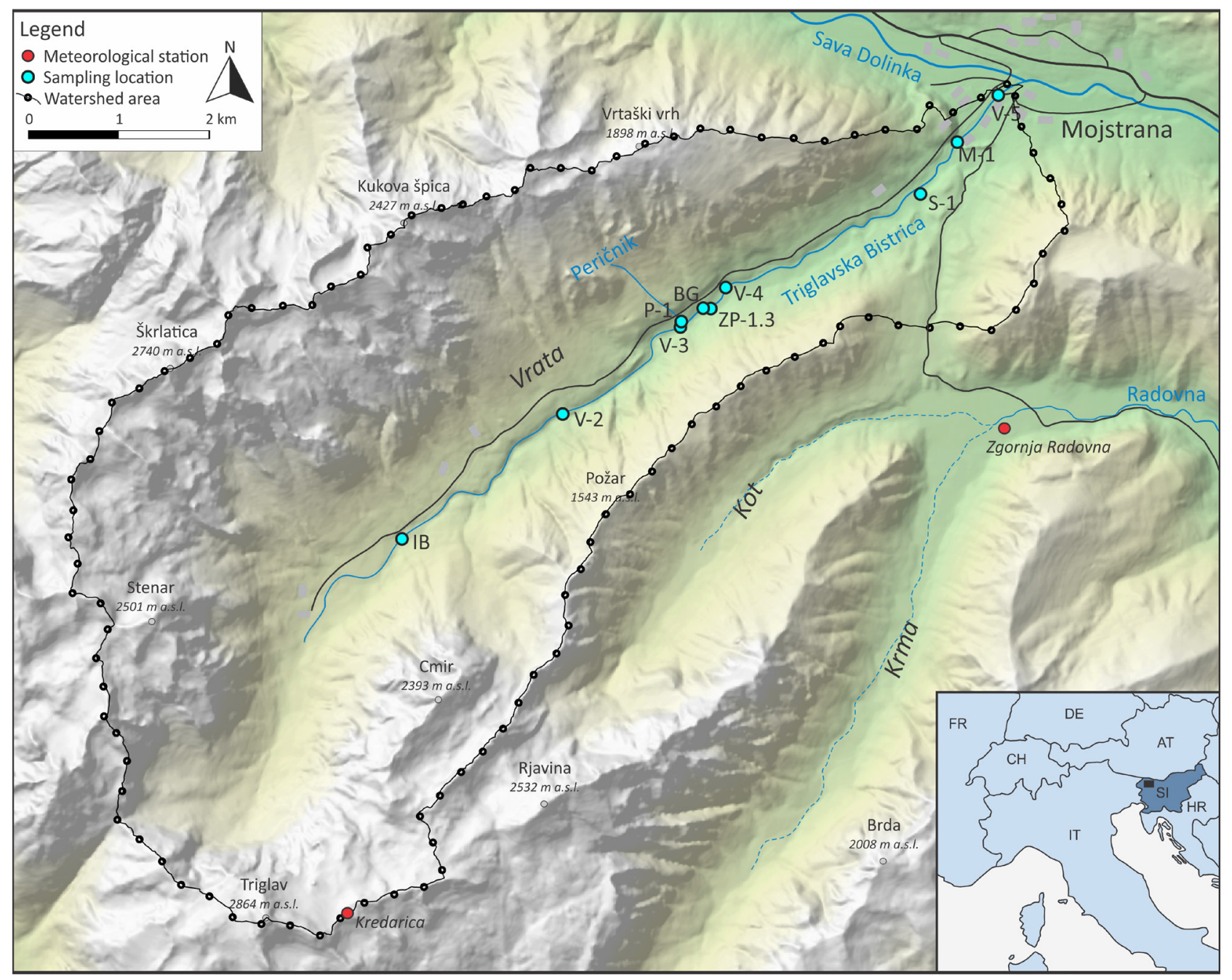

Fig. 1. The observation area and sampling locations (spring MS-1 is not included due to its distance from the Vrata Valley; coordinates of the spring are given in Table 1).

runoff is amplified by lateral inflows. The river discharge is classified as an alpine high mountain snow-rain regime (Hrvatin, 1998), and the effects of snowmelt are still evident in late summer; but in the fall the runoff originates just below the north face of the Triglav Mountain. In shaded kettles and mountain gorges the snow remains all year round.

The wider observation area (Fig. 1) is characterized by a variety of relief forms, fast and expressive altitude changes due to the geological base, and process related to the formation of younger mountains. The landscape is characterized by glacially-formed valleys and rocky highland ridges, peaks with unusual karstic shapes. They climb over the Gate Valley Stenar $(2,601 \mathrm{~m})$, Škrlatica $(2,740 \mathrm{~m})$, Kukova Špica $(2,427 \mathrm{~m})$ and above the junction of the valley's Severna Triglav wall. Some high peaks can be found also in the ridge that divides Vrata and Kot, for example Cmir $(2,393 \mathrm{~m})$ and Rjavina $(2,532 \mathrm{~m})$. The catchment area of the Triglavska Bistrica is overgrown with forest in its lower part. At the foot of the valley, glaciers that probably covered the entire Upper Sava Valley (Serianz, 2016) have left behind well consolidated lateral moraines that cause, together with other hydrological parameters, a slower run-off from the valley slopes (Smolar-Žvanut et al., 2005). The diversity of the Alpine valleys influences the climate there, especially temperature (regime of alpine basins and valleys, ridges, and peaks).

\section{Hydrometeorological data}

The climate of the Upper Sava region belongs to the Alpine region, which is characterized by long and snowy winters and short, moderately warm summers, frequent east winds and abundant rainfall. The area along the Vrata Valley is still under the influence of specific climatic conditions, which aggravate the mountainous character of the climate and is a consequence of the altitude. Winter usually lasts four to five months. The average minimum daily temperature in January 
is as low as $-8{ }^{\circ} \mathrm{C}$, while during the day it can warm above $0{ }^{\circ} \mathrm{C}$. In the warmest month, daytime temperatures rise to $23^{\circ} \mathrm{C}$. Across the valley upwards, the microclimatic conditions vary even more. An indicator of this is the thickness of the snow cover, which grows with each meter in altitude. There are also large differences between sunny and shady slopes in winter. Thus, sunny slopes in winter are suitable for trips and walks, because they offer the desired sunlight, and shady slopes protect and preserve the snow blanket. At Kredarica meteorological station, which is located at an altitude of $2,514 \mathrm{~m}$, the climate is even more significantly affected by snow. Here, the snow can be as much as an estimated $7 \mathrm{~m}$ deep (Nadbath, 2014). Based on the meteorological data available on the web database of the Slovenian Environmental Agency - ARSO (Internet 1), in the period from September 2019 to September 2020, which was representative for the documented hydrogeological investigations, winter temperatures dropped to $-20^{\circ} \mathrm{C}$, while during the summer they rise to more than $20^{\circ} \mathrm{C}$ (Fig. 2). During this period snow was present from November to July, a full 8 months, with snow up to $4 \mathrm{~m}$ deep. The specific alpine meteorological conditions also affect the Triglavska Bistrica River hydrograph. Data from past observation at the gauging station in Mojstrana (Internet 2) indicate the presence of a snow-rainy river flow regime, with the largest discharges during the melting period in spring (Fig. 3).

\section{Hydrogeological settings}

The Triglavska Bistrica River recharges from the watershed area extending from the southern side of the Triglav Mountains and the ridges above the Vrata Valley. In this area massive limestones and dolomites and granular dolomites predominate (Jurkovšek, 1987). From a hydrogeological point of view, the carbonate layers, limestones and dolomites form aquifers with fissure, karstic, and karstic-fissure porosity. Faults in the Dinaric and Trans-Dinaric directions run through the catchment area, which influence the geometry of the aquifer. In the lower areas, the carbonate rocks are covered with poorly sorted moraine material and sloping sediments, which are sometimes filled with unsorted clay and sand deposits and are mostly presented by good or medium hydraulic conductivity; however, also low hydraulic conductivity can be observed due to the high heterogeneity of the sediment structure (e.g. clay, silt). Intermediate clay inserts represent hydraulic barriers. The sediments are of glaciofluvial origin (Jurkovšek, 1987). Slope sediments and moraines can be found at the bottom of the Valley, covering the bedrock slopes. These Quaternary deposits are determined by intergranular porosity with good to low hydraulic conductivity. Alluvial deposits of Holocene age up to a few meters thick can also be found along the riverbanks. The alluvial sediments that occur at the bottom of the valley where the Triglavska Bistrica flows represent a highly-permeable and relatively homogeneous intergranular aquifer.

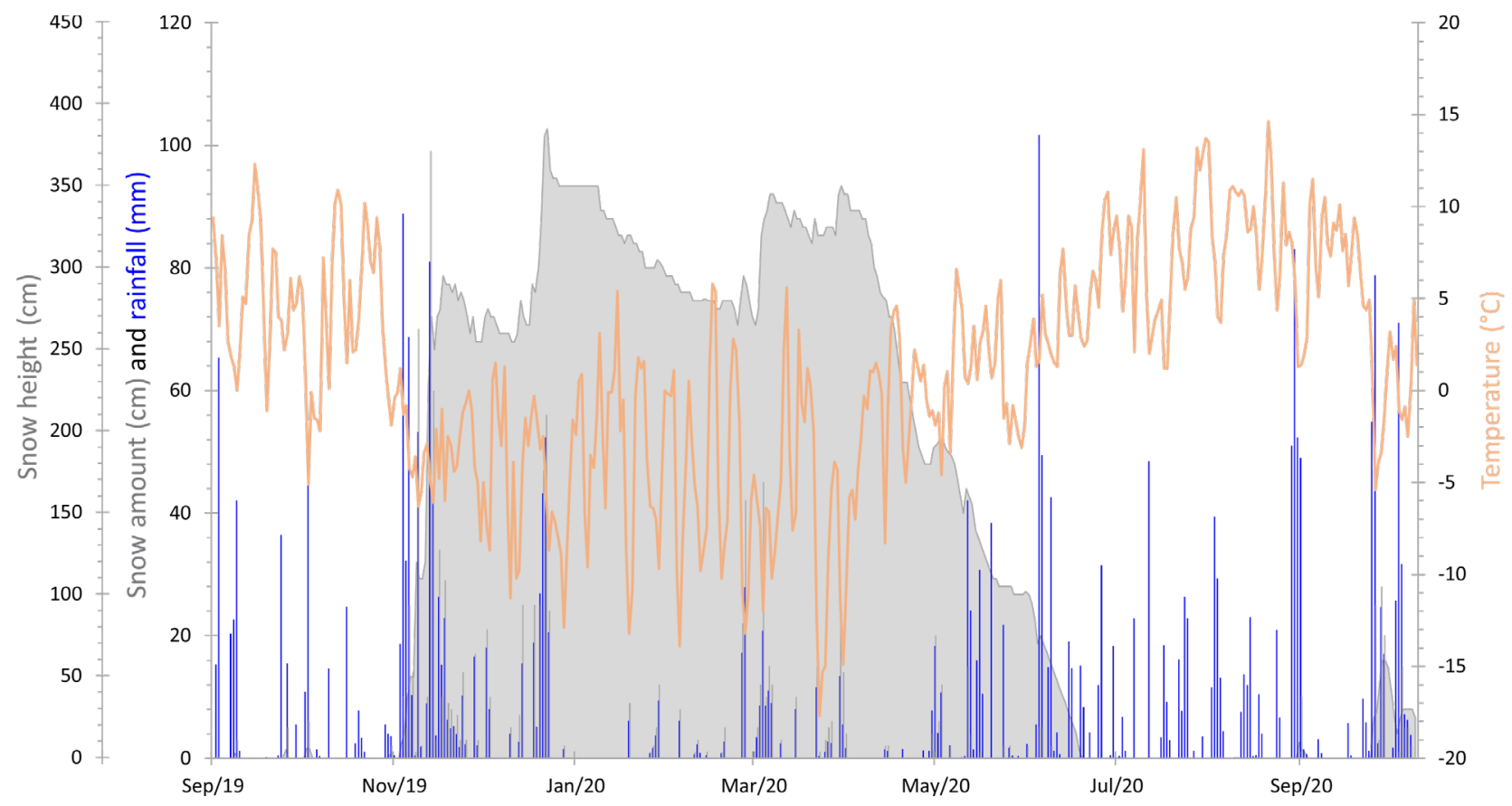

Fig. 2. Meteorological data at the Kredarica station for the period September 2019 to September 2020 (ARSO, 2021). 


\section{Materials and methods}

\section{Gauging station M-1}

In the past, regular flow measurements were made at the Triglavska Bistrica River. In the period 1953 to 1990 , a water gauging station operated on the Bistrica River in the village of Mojstrana. The surface area of the catchment area of the Bistrica to the gauging station of Mojstrana is $47 \mathrm{~km}^{2}$. Since no flow measurements have been made since 1989, a flow tube near the small hydroelectric plant at Mojstrana (M-1) was installed on April 10, 2020, which contains a "diver" that we use to monitor the flow elevation of the Triglavska Bistrica. This monitoring site is located further upstream $(\sim 700 \mathrm{~m})$ than the original gauges Mojstrana and Mojstrana I. Discharge measurements were performed along the stretch where monitoring site M- 1 is located. The measurements were made using the instant chemical integration method, which is based on the immediate injection of tracers into the river. As a follow-up, common table salt was used, which provides a series of quality measurements due to its physicochemical properties (highly soluble in water, harmless to the environment, etc.) and leads to a strong increase in electrical conductivity. The salt concentration was measured based on electrical conductivity using a "Flo-tracer" measuring device. Based on periodic measurements and a comparison with the measured flow height in the pipe at gauging station M-1 a preliminary stage-discharge rating curve was constructed (power type). Currently, only three representative values are available for adjusting stage-discharge rating curve.

\section{Water sample collection}

Sampling of groundwater and surface water from the Peričnik catchment and springs, as well as from the wider area (Fig. 1), was carried out with the aim of determining the hydrogeological conditions of the recharge area of the Peričnik springs, which are important for the water supply for the western part of the municipality of Jesenice. The joint discharge rate of Peričnik springs ranges from 70 to $120 \mathrm{~L} / \mathrm{s}$ and supplies some 15,000 users (Internet 3).

Roughly speaking, the monitoring sites were selected based on preliminary cartographic analysis and knowledge of the hydrogeological conditions of the area. The exact location for each monitoring site was determined in the field (Fig. 1, Table 1). At the first sampling, we selected 10 monitoring sites, 6 of which are represented by
Triglavska Bistrica surface water (V-2, V-3, BG, V-4, V-5, M-1), one in the Peričnik stream (P-1), one in the captured Peričnik spring (ZP-1.3), and two surrounding springs (S-1 and MS-1). During the second sampling, we added another monitoring site, Triglavska Bistrica (IB), in addition to the existing ones.

Sampling was conducted in two campaigns, on April 10, 2020 and May 22, 2020. According to the recorded flows at monitoring site M-1 (Fig. 3), the first sampling was conducted at low water level, and the second sampling was conducted at medium water level. Sampling procedures, transport and storage of groundwater samples were carried out in accordance with ISO standards (SIST ISO 5677-11:1996; SIST ISO 5677-03:1996; SIST ISO 5677-6:1996).

In-situ measurements of physico-chemical parameters (i.e. temperature $(\mathrm{T}), \mathrm{pH}$, and electrical conductivity (EC)) were carried out using a waterproof HI98194 multimeter from HANNA instruments Inc. (Hanna instruments, 2020). The reported analytical accuracies of the field measurements are \pm 0.02 for $\mathrm{pH}, \pm 0.15{ }^{\circ} \mathrm{C}$ for temperature and $\pm 1 \%$ for electrical conductivity.

Water samples were collected to determine the isotopic composition of oxygen $\left(\delta^{18} \mathrm{O}\right)$ and hydrogen $\left(\delta^{2} \mathrm{H}\right)$. Based on the results of the first sampling and in order to get valuable insight into the hydrogeochemical processes and the natural background of the wider area samples for determination additional parameters were collected during the second sampling. Water samples for basic chemical parameters (i.e. $\mathrm{Na}^{+}, \mathrm{K}^{+}, \mathrm{Ca}^{2+}, \mathrm{Mg}^{2+}$, $\mathrm{HCO}_{3}{ }^{-}, \mathrm{SO}_{4}{ }^{2-}, \mathrm{Cl}^{-}, \mathrm{NO}_{3}{ }^{-}$and total dissolved solids) were collected at 5 locations, and at 3 locations for tritium activity concentration $\left({ }^{3} \mathrm{H}\right)$ (Table 1 ).

Precipitation is sampled according to the most rational approach for monitoring isotopes in precipitation as a monthly composite in the frame of the Slovenian Network of Isotopes in Precipitation (Vreča and Malenšek, 2016, Internet 4) at two meteorological stations (i.e. Kredarica and Zgornja Radovna), which are part of the Slovenian National Meteorological Network maintained by the Slovenian Environmental Agency (ARSO). Precipitation samples were collected by ARSO staff from the classical rain gauge collector three times daily (synoptic station Kredarica) or once per day (precipitation station Zgornja Radovna). The volume of collected precipitation is recorded and the sample is poured into a plastic bottle with a tight-fitting cap. In the laboratory, we removed impurities (e.g. dust, particles) from the composite monthly sample by filtration through 
12-25 $\mu \mathrm{m}$ pore-size ashless filter papers before taking aliquots for different isotope analyses. Samples for the analysis of stable isotopes of hydrogen and oxygen were stored in glass bottles (minimum $30 \mathrm{~mL}$ ).

\section{Chemical analysis}

Chemical analysis of major ions was performed by the Slovenian National Laboratory of Health, Environment and Food, Novo mesto laboratory, in accordance with the lab's methods (accreditation document LP-014, last modification 14 February 2020). For the basic chemical parameters $\left(\mathrm{Na}^{+}, \mathrm{K}^{+}\right.$, $\mathrm{Ca}^{2+}, \mathrm{Mg}^{2+}, \mathrm{SO}_{4}{ }^{2-}, \mathrm{Cl}^{-}, \mathrm{NO}_{3}{ }^{-}$) the ion chromatography method (SIST EN ISO 10304-1:2009, SIST EN ISO 17294-2:2005, SIST EN ISO 14911:2000) was used, and for $\mathrm{HCO}_{3}^{-}$the volumetric method was used (EN ISO 9963-1). The measurement uncertainty for $\mathrm{NO}_{3}{ }^{-}$is $\pm 11 \%$, for $\mathrm{SO}_{4}{ }^{2-} \pm 8 \%$, for $\mathrm{Cl}^{-} \pm 7 \%$, for $\mathrm{Ca}^{2+} \pm 15 \%$, for $\mathrm{Mg}^{2+} \pm 12 \%$, for $\mathrm{Na}^{+} \pm 11 \%$, for $\mathrm{K}^{+} \pm 12 \%$, and for $\mathrm{HCO}_{3}{ }^{-} \pm 3 \%$.

The isotopic composition of hydrogen $\left(\delta^{2} \mathrm{H}\right)$ and oxygen $\left(\delta^{18} \mathrm{O}\right)$ was determined at the Jožef Stefan Institute (Ljubljana, Slovenia) using the $\mathrm{H}_{2}-\mathrm{H}_{2} \mathrm{O}$ (Coplen et al., 1991) and $\mathrm{CO}_{2}-\mathrm{H}_{2} \mathrm{O}$ (Epstein and Mayeda, 1953; Avak et al., 1995) equilibration technique. Measurements were performed using a dual inlet isotope ratio mass spectrometer (DI IRMS, Finnigan MAT DELTA plus, Finnigan MAT GmbH, Bremen, Germany) with an automated $\mathrm{CO}_{2}-\mathrm{H}_{2} \mathrm{O}$ and $\mathrm{H}_{2}-\mathrm{H}_{2} \mathrm{O}$ HDOeq 48 Equilibration Unit (custom-made by M. Jaklitsch). All measurements were performed together with laboratory reference materials (LRM) that are regularly calibrated against primary IAEA calibration standards. Water samples were measured as independent duplicates. Results were normalized to the VSMOW/SLAP scale using the Laboratory Information Management System (LIMS) for Light Stable Isotopes (U.S. Geological Survey) and expressed in standard $\delta$ notation (in $\%)$. For independent quality control, we used a LRM W-45 with defined isotopic values and an estimated measurement uncertainty of $\delta^{2} \mathrm{H}=$ $-60.6 \pm 0.7 \%$ and $\delta^{18} \mathrm{O}=-9.12 \pm 0.04 \%$, and the commercial reference materials USGS $45\left(\delta^{2} \mathrm{H}=\right.$ $-10.3 \pm 0.2 \%, \delta^{18} \mathrm{O}=-2.238 \pm 0.006 \%$ o) and USGS $47\left(\delta^{2} \mathrm{H}=-150.2 \pm 0.3 \%\right.$ o, $\delta^{18} \mathrm{O}=-19.80 \pm 0.01 \%$ ). The average sample repeatability for $\delta^{2} \mathrm{H}$ and $\delta^{18} \mathrm{O}$ was 0.3 and $0.01 \%$, respectively.

Groundwater samples for determination of the tritium activity concentration $\left({ }^{3} \mathrm{H}\right)$ were analysed by the Wessling laboratory in Budapest using the IRPA standard (FS-78-15-AKU: 1995) and MSZ 19387:1987 method. This procedure is based on the principal of selective isotopic enrichment using electrolysis. The volumes of the water samples are reduced from $250 \mathrm{~mL}$ or $800 \mathrm{~mL}$ to 14 $15 \mathrm{~mL}$ by electrolytic enrichment, with the factor of tritium enrichment roughly $15-16$ or $30-35$. The tritium activity of enriched water samples was counted using a liquid scintillation analyser (LD: 0.5 or $0.2 \mathrm{TU}$, the uncertainty is $5-10 \%$ ).

\section{Data interpretation models}

\section{Hydrogeochemistry}

Graphical analysis classification of groundwater type was performed in an AquaChem ${ }^{\circledR} 5.1$ (Waterloo Hydrogeologic Inc., Waterloo, Canada), where the ion pattern was defined according to the concentration of dominant dissolved species measured in the groundwater. A trilinear Piper diagram (Piper, 1944) was used to determine hydrochemical facies using all major ions for classification. In addition, the molar ratio between $\mathrm{Ca}^{2+}$ and $\mathrm{Mg}^{2+}$ in groundwater was used to indicate the relative proportion of rocks in the recharge area. However, values equal to 1 are assumed in the literature to indicate dissolution of dolomite and dolomite prevailing in the recharge area (Mayo and Loucks, 1995). A higher $\mathrm{Ca}^{2+} / \mathrm{Mg}^{2+}$ molar ratio $(>2)$ is a consequence of the predominant calcite rocks (Katz, 1998). The saturation indices (SI) of dolomite and calcite were calculated to evaluate the chemical equilibrium using an AquaChem ${ }^{\circ}$ 5.1 , based on the following equation:

$$
S I=\log \left(I A P / K_{T}\right)
$$

where IAP is the ion activity product and $\mathrm{K}_{\mathrm{T}}$ the equilibrium constant at a given temperature. Positive SI values (SI >0) indicate mineral oversaturation and precipitation, while negative SI values $(\mathrm{SI}<0)$ indicate unsaturated solutions and mineral dissolution. The assumed tolerance equilibrium range with respect to mineral is \pm 0.1 SI for calcite and \pm 0.5 SI for dolomite.

\section{Stable isotopes}

The stable isotope composition of groundwater $\left(\delta^{18} \mathrm{O}\right.$ and $\left.\delta^{2} \mathrm{H}\right)$ was used to obtain information on the characteristics of the recharge area. The $\delta^{18} \mathrm{O}$ and $\delta^{2} \mathrm{H}$ values were compared with:

- the Global Meteoric Water Line (GMWL) defined as $\delta^{2} \mathrm{H}=8 \delta^{18} \mathrm{O}+10$ (\%) (Craig, 1961), which is very close to the local meteoric water line for the Ljubljana 1981-2010 precipitation isotope record (Vreča et al., 2008 and 2014; Internet 4), 
- the Eastern Mediterranean Meteoric Water Line (EMMWL) defined as $\delta^{2} \mathrm{H}=8 \delta^{18} \mathrm{O}+22$ (Gat and Carmi, 1970), and

- the precipitation-weighted local meteoric water lines (reduced major axis regression RMA) for Kredarica defined as $\delta^{2} \mathrm{H}=8.4 \delta^{18} \mathrm{O}+$ 19 and for Zgornja Radovna defined as $\delta^{2} \mathrm{H}=$ $8 \delta^{18} \mathrm{O}+11$ (Internet 4$)$.

The $\delta^{18} \mathrm{O}$ values were also used to determine the mean recharge altitude of the investigated water samples. The calculations used herein were based on:

1. $\delta^{18} \mathrm{O}$ altitude effect from precipitation in the period 2016-2020 at Kredarica and Zgornja Radovna meteorological stations. Calculations were made separately for snow and total precipitation. The $\delta^{18} \mathrm{O}$ of snow was determined by a detailed analysis of precipitation data for each monthly sampling campaign at the meteorological station. For $\delta^{18} \mathrm{O}$ of snow, only those samples where the snow represents $60 \%$ or more of total precipitation $\left(\mathrm{P}_{\text {snow }} \geq 0.6 \mathrm{P}_{\text {total }}\right)$ were counted. Spring MS-1 average $\delta^{18} \mathrm{O}$ from both samplings was used as a representative value for applying precipitation mean altitude effect.
2. archive mean altitude effect calculated for Radovna Valley (Torkar et al., 2016) based on linear model $\mathrm{h}_{\mathrm{avg}}=-931.8 \delta^{18} \mathrm{O}-7650.8$ and Bled area (Serianz et al., 2020b) based on linear model $\mathrm{h}_{\mathrm{avg}}=-939.2 \delta^{18} \mathrm{O}-7518.6$.

\section{Results and discussion}

\section{Triglavska Bistrica hydrograph}

The highest measured discharge at the gauging station M-1 for the preliminary stage-discharge rating curve adjustment was $9 \mathrm{~m}^{3} / \mathrm{s}$, while measurements at higher water levels were unsuccessful due to unfavourable measurement conditions. Therefore, the information on some peak discharges above $9 \mathrm{~m}^{3} / \mathrm{s}$ (Fig. 3) is relatively poor and will be improved in the future. The Triglavska Bistrica hydrograph shows the measurements (average daily flow, maximum daily flow, and minimum daily flow) from 1973 to 1989 (Internet 2). At the same time, the hydrograph shows the flow for 1980, which was chosen as the reference flow for this period of operation at measuring point Mojstrana I. The archive discharges (Internet 2) are presented for comparison with new measurement at gauging station M-1.

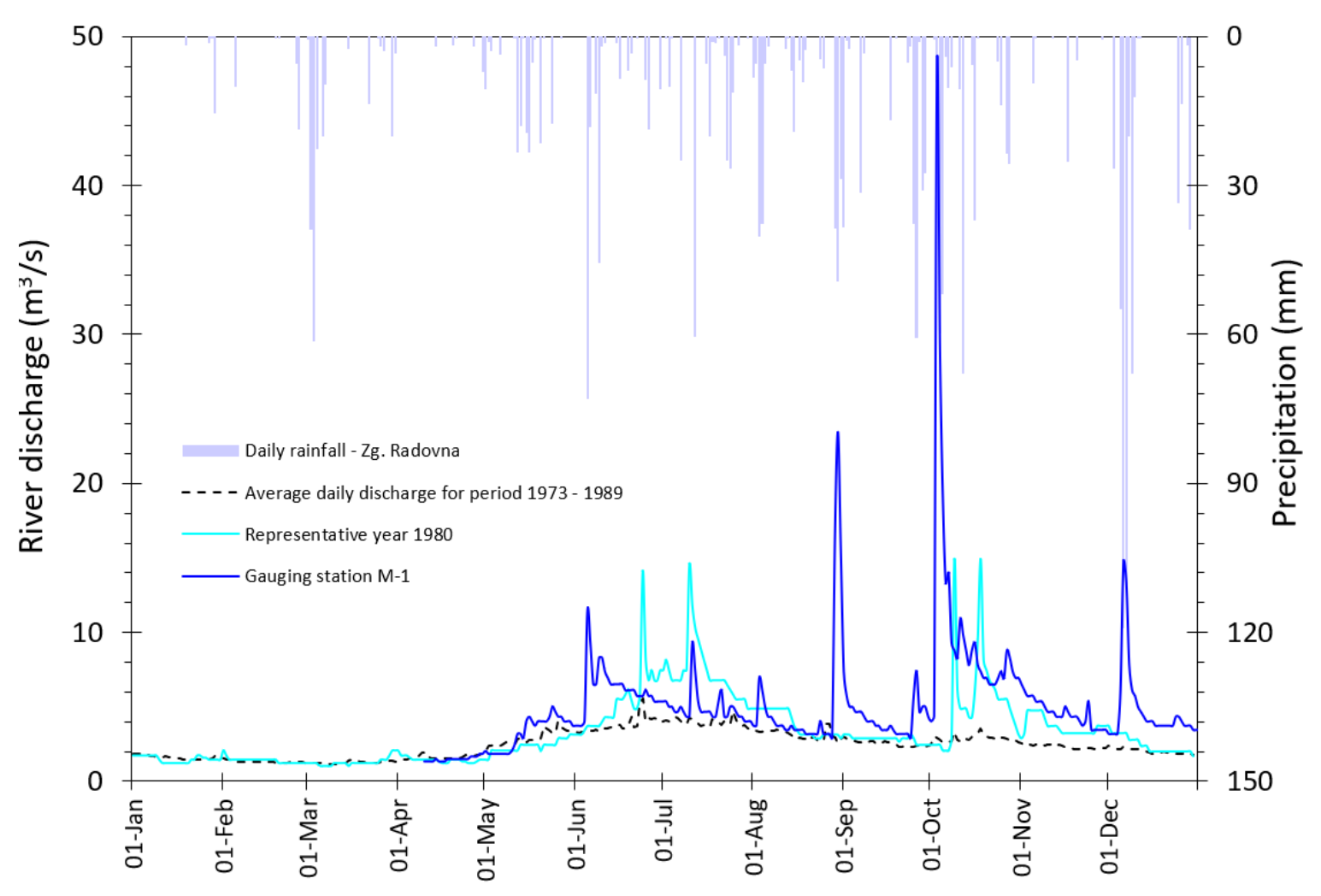

Fig. 3. Triglavska Bistrica River hydrography at gauging station M-1 and archive gauging station Mojstrana, including daily precipitation at the Zgornja Radovna meteorological station. 
The Triglavska Bistrica hydrograph illustration has a specific shape, which can be described with snow-rain regime. It can be divided into two parts: (1) period of snow thaw and (2) autumn rainy period (Fig. 3). The start of the snow-melt period can be detected by the small discharges in early spring, which start with the slow rise of discharges, and during the high-thaw period form a specific shape with high discharge values. A few discharge peaks can be observed from the resulting shape as the result of rainy day(s) in the snow-melt period. Once the highest discharge is reached, usually at the beginning of summer, it starts to decline.

\section{Physio-chemical parameters}

The results of the measurements of field parameters, basic chemical analysis, isotopic composition of $\delta^{18} \mathrm{O}$ and $\delta^{2} \mathrm{H}$, and tritium activity concentrations in groundwater and surface water are summarised in Table 1. Water temperatures in the Peričnik catchment (sampling point ZP1.3) were 6.0 and $6.1^{\circ} \mathrm{C}$ in both sampling campaigns, and slightly higher in surface waters and springs, between 5.7 and $8.3{ }^{\circ} \mathrm{C}$ (average $7.0{ }^{\circ} \mathrm{C}$ ) in the first campaign, and between 7.2 and $9.5^{\circ} \mathrm{C}$ (average $8.0^{\circ} \mathrm{C}$ ) in the second sampling campaign. The $\mathrm{pH}$ value of the groundwater in the Peričnik catchments was constant at 8.0 in the first campaign, and 7.9 in the second campaign. The surface water of the Triglavska Bistrica (sampling point BG) has similar values about $100 \mathrm{~m}$ upstream from the Peričnik catchments (8.3 and 8.1 , respectively). The $\mathrm{pH}$ values in the surface water ranged from 8.2 to 8.4 and from 7.2 to 8.3 in the second campaign. The electrical conductivity (EC) of the groundwater in the Peričnik catchment was $192 \mu \mathrm{S} / \mathrm{cm}$ in the first sampling campaign and $187 \mu \mathrm{S} / \mathrm{cm}$ in the second sampling campaign. Similar EC values are also characteristic for the sampling point $\mathrm{BG}$, at 188 $\mu \mathrm{S} / \mathrm{cm}$ in the first sampling campaign or slightly lower $(173 \mu \mathrm{S} / \mathrm{cm})$ in the second sampling campaign and at spring S-1 (between 195 and $276 \mu \mathrm{S} /$ $\mathrm{cm})$. The EC values are lower at the surface water sampling points and range between 110 and 146 $\mu \mathrm{S} / \mathrm{cm}$ (average $127.5 \mu \mathrm{S} / \mathrm{cm}$ ) in the first sampling campaign. In the second sampling campaign, the values are higher and range between 153 and 201 $\mu \mathrm{S} / \mathrm{cm}$ (average $180 \mu \mathrm{S} / \mathrm{cm}$ ). In the second sampling campaign, the Bistrica spring (IB) was also sampled, where the measured value from EC was $234 \mathrm{\mu S} / \mathrm{cm}$.

The basic chemical parameters were only determined in the second campaign, so a compar- ison of the results between the two sampling campaigns is not possible. The $\mathrm{Ca}^{2+}$ concentration in the groundwater in the Peričnik catchment is about $26 \mathrm{mg} / \mathrm{L}$. A similar $\mathrm{Ca}^{2+}$ concentration was also measured at sampling point P-1 (26 $\mathrm{mg} / \mathrm{L}$ ), and slightly higher at sampling point BG $(28 \mathrm{mg} / \mathrm{L})$. Upstream of the Peričnik catchment (sampling points V-3 and IB), $\mathrm{Ca}^{2+}$ concentrations in surface water are slightly higher, reaching 30 and $42 \mathrm{mg} / \mathrm{L}$, respectively. $\mathrm{Mg}^{2+}$ concentrations indicate the opposite. In the Peričnik catchment, slightly higher concentrations are measured in groundwater $(8.4 \mathrm{mg} / \mathrm{L})$, while at upstream sampling points $\mathrm{V}-3, \mathrm{BG}, \mathrm{IB}$ and $\mathrm{P}-1, \mathrm{Mg}^{2+}$ concentrations range between 5.7 and $7.6 \mathrm{mg} / \mathrm{L}$ and increase downstream towards the Peričnik catchment. Characteristics similar to those of $\mathrm{Ca}^{2+}$ in the water are also reflected in the distribution of $\mathrm{HCO}_{3}{ }^{-}$concentrations in the water. The highest concentrations of $\mathrm{HCO}_{3}^{-}$in the water were measured at the sampling point IB (160 $\mathrm{mg} / \mathrm{L}$ ). The concentrations decrease downstream and reach $129 \mathrm{mg} / \mathrm{L}$ at sampling point BG. Similar concentrations were also measured in the water of the Peričnik catchment (124 mg/L).

The values of carbonate ions $\left(\mathrm{Ca}^{2+}, \mathrm{Mg}^{2+}\right.$, and $\mathrm{HCO}_{3}^{-}$) in the groundwater indicate the carbonate recharge area. The calculated ratio between calcium and magnesium ions $\left(\mathrm{Ca}^{2+}+\mathrm{Mg}^{2+}\right)$ and $\mathrm{HCO}_{3}{ }^{-}$in meq/L is about $1: 1$. The water samples belong to the $\mathrm{Ca}-\mathrm{Mg}-\mathrm{HCO}_{3}$ facies, with low $\mathrm{K}^{+}, \mathrm{Na}^{+}, \mathrm{Cl}^{-}, \mathrm{NO}_{3}{ }^{-}$and $\mathrm{SO}_{4}{ }^{2-}$ ion-content, except for the water at the sampling point IB, which belongs to the $\mathrm{Ca}-\mathrm{HCO}_{3}$ facies (Fig. 4). The $\mathrm{Ca}^{2+} /$ $\mathrm{Mg}^{2+}$ molar ratio for each sampling point shows similar characteristics (Fig. 5a). The $\mathrm{Ca}^{2+} / \mathrm{Mg}^{2+}$ ratio is 2.0 for the groundwater in the Peričnik catchment, while the ratio for the surface water upstream of the catchment is slightly higher (between 2.39 and 2.61), and is highest for sampling point IB (4.32). The latter shows that the recharge area of the spring is an aquifer dominated by limestone, while other waters are characterized as mainly fed by aquifers dominated by dolomite over limestone.

Figure 5b shows saturation indices (SI) of calcite $\left(\mathrm{SI}_{\text {calcite }}\right)$ and dolomite $\left(\mathrm{SI}_{\text {dolomite }}\right)$ in sampled water. Groundwater at sampling point IB is oversaturated with respect to calcite and dolomite, since $\mathrm{SI}_{\text {calcite }}$ and $\mathrm{SI}_{\text {dolomite }}$ are both positive $(\mathrm{SI}>0)$, which means that the mineral might precipitate but cannot dissolve (Appelo and Postma, 2005). This groundwater was sampled in the recharge area where limestone prevails. 


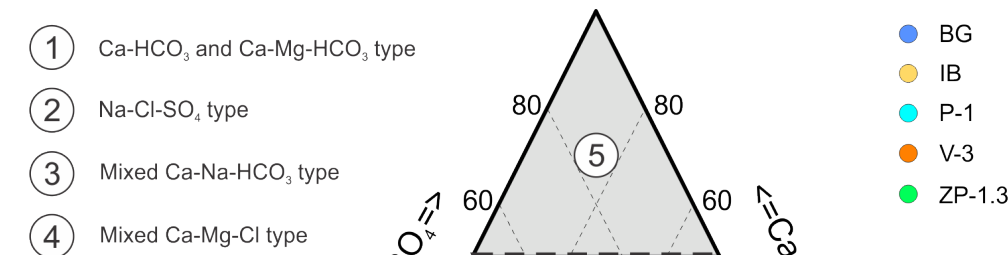
(5) Ca-Cl type
(6) $\mathrm{Na}-\mathrm{HCO}_{3}$ type
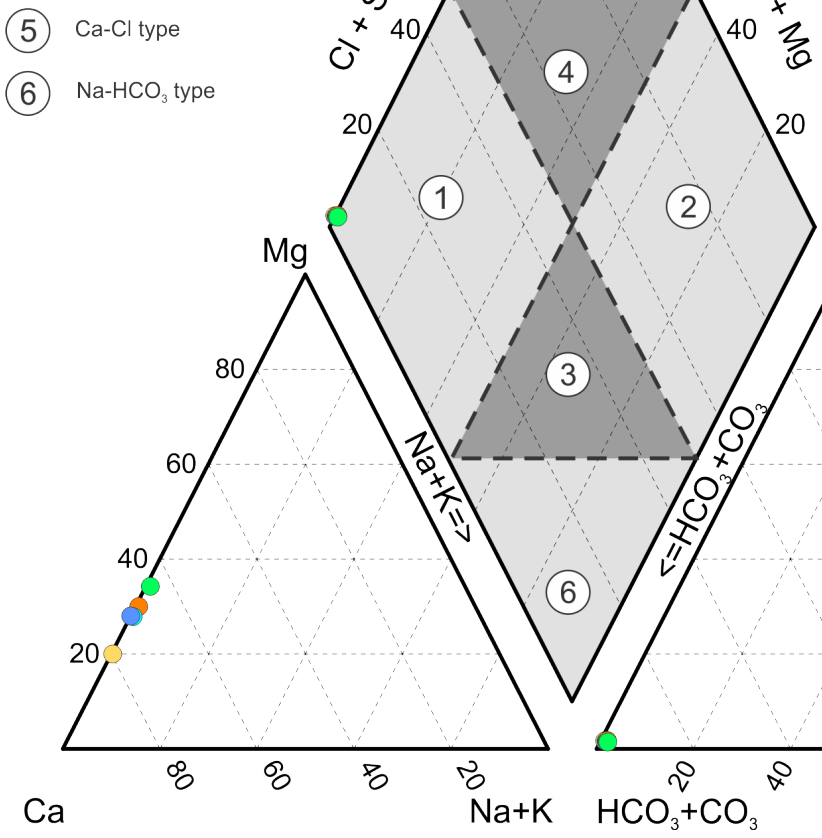

Fig. 4. Graphical analysis of water samples with Piper diagram.

Water at all other sampling points (ZP-1.3, $\mathrm{V}-3$ in $\mathrm{P}-1$ ) is unsaturated with respect to calcite and dolomite, since $\mathrm{SI}_{\text {calcite }}$ and $\mathrm{SI}_{\text {dolomite }}$ are both negative $(\mathrm{SI}<0)$ except $\mathrm{BG}$, where $\mathrm{SI}_{\text {calcite }}$ is approx. zero. The latter shows that minerals may not be reacting at all or may be reacting reversibly, in which case the mineral could be dissolving or precipitating (Appelo and Postma, 2005). The surface water at sampling point V-3 is highly unsaturated with respect to very low $\mathrm{SI}_{\text {dolomite }}$ values, where also the lowest $\mathrm{pH}$ value (7.2) is observed. In this case the mineral might dissolve very slowly or not at all, depending on the kinetics of the reaction (Appelo and Postma, 2005).

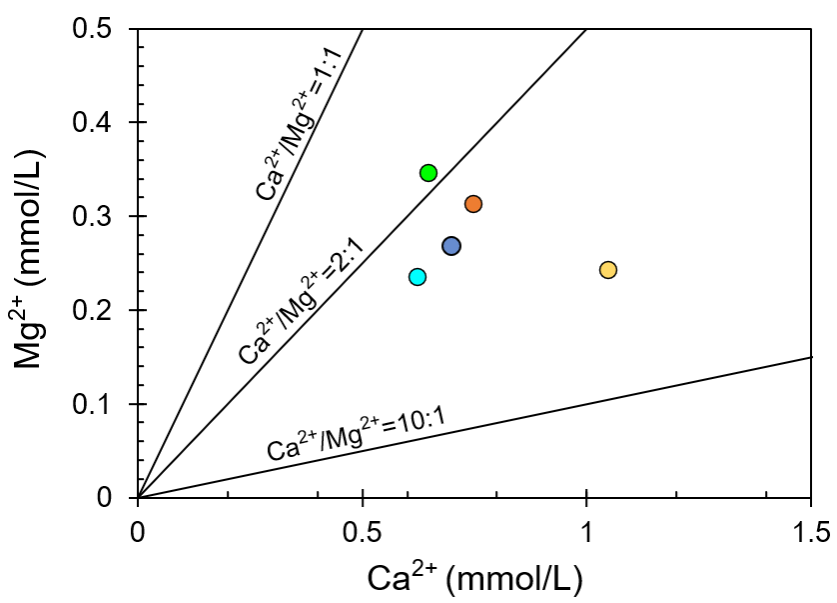

The measured concentrations of other basic chemical parameters are low and do not indicate significant pollution of groundwater and surface water. Nitrate concentrations $\left(\mathrm{NO}_{3}^{-}\right)$in groundwater are below $1.95 \mathrm{mg} / \mathrm{L}$, which is below the expected natural background (5 mg/L) (Serianz et al., 2020a). Sulphate concentrations $\left(\mathrm{SO}_{4}{ }^{2-}\right)$ range from 0.76 to $1.40 \mathrm{mg} / \mathrm{L}$ and chloride concentrations $\left(\mathrm{Cl}^{-}\right)$range from 0.21 to $0.30 \mathrm{mg} / \mathrm{L}$. No major differences between the sampling point of the Peričnik catchment (ZP-1.3) and surface water or springs were detected.

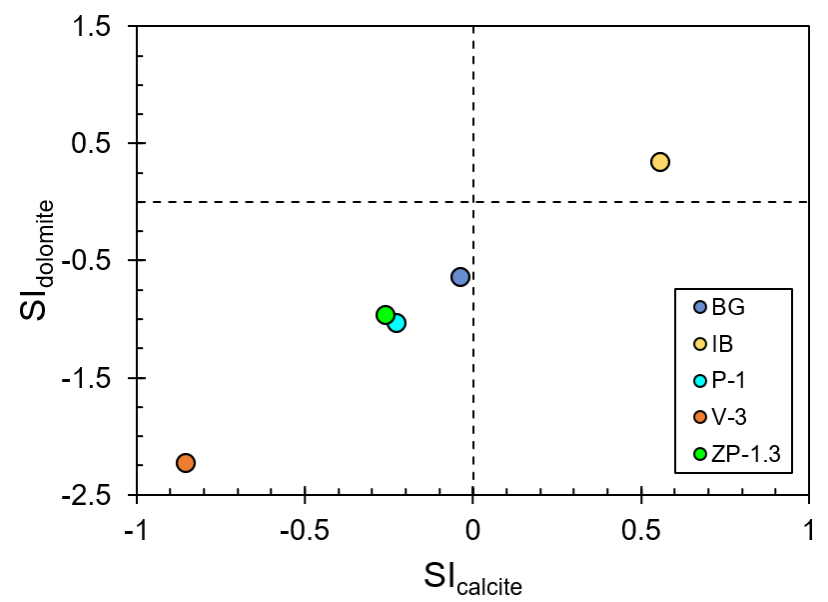

Fig. 5. Scatter plots of a) $\mathrm{Mg}^{2+}(\mathrm{mmol} / \mathrm{L})$ versus $\mathrm{Ca}^{2+}(\mathrm{mmol} / \mathrm{L})$ and b) $\mathrm{SI}_{\text {calcite }}$ versus $\mathrm{SI}_{\text {dolomite }}$. 


\begin{tabular}{|c|c|c|c|c|c|c|c|c|c|c|c|c|c|c|c|c|c|c|c|c|c|c|}
\hline \multirow{2}{*}{ वृ้ } & $\stackrel{\circ}{\circ}$ & $\tilde{o}$ & $\stackrel{m}{0}$ & $\stackrel{m}{0}$ & - & $\stackrel{t}{0}$ & $\overrightarrow{0}$ & $\overrightarrow{0}$ & 3 & ฮี & $\tilde{O}$ & $\overrightarrow{0}$ & $\hat{0}$ & $\overrightarrow{0}$ & $\hat{0}$ & 今) & $\because$ & $\because$ & 3 & 3 & $\overrightarrow{0}$ & ? \\
\hline & $\therefore$ & $\begin{array}{l}0 \\
\dot{0} \\
\dot{0}\end{array}$ & $\begin{array}{l}\text { foj } \\
\dot{f} \\
\end{array}$ & $\begin{array}{l}+ \\
\stackrel{0}{0} \\
1\end{array}$ & $\begin{array}{l}\infty \\
0 \\
0 \\
1\end{array}$ & $\begin{array}{l}\infty \\
0 \\
0 \\
1\end{array}$ & $\begin{array}{l}\infty \\
0 \\
0 \\
1\end{array}$ & 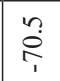 & 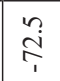 & 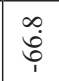 & \begin{tabular}{|l|} 
\\
0 \\
0 \\
0
\end{tabular} & $\begin{array}{l}\infty \\
0 \\
0 \\
1\end{array}$ & $\begin{array}{l}2 \\
\hat{b} \\
1\end{array}$ & \begin{tabular}{|l|}
1 \\
0 \\
0 \\
1
\end{tabular} & \begin{tabular}{|l|}
$n$ \\
0 \\
0 \\
1
\end{tabular} & \begin{tabular}{|l|} 
\\
$\dot{\hat{Q}}$ \\
\end{tabular} & $\begin{array}{l}\infty \\
\stackrel{1}{0} \\
\stackrel{1}{1}\end{array}$ & $\frac{m}{i}$ & 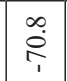 & $\stackrel{m}{i}$ & 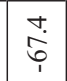 & $\overline{\text { s. }}$ \\
\hline \multirow{2}{*}{ 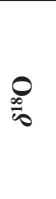 } & $\mid \begin{array}{c}\circ \\
\stackrel{\circ}{+}\end{array}$ & $\overrightarrow{0}$ & $\stackrel{8}{0}$ & $\stackrel{8}{0}$ & $\overrightarrow{0}$ & $\overrightarrow{\dot{o}}$ & $\stackrel{8}{\circ}$ & $\dot{0}$ & $\stackrel{0}{\circ}$ & ठ̊. & $\overrightarrow{0}$ & 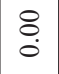 & 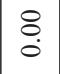 & $\stackrel{8}{\circ}$ & $\stackrel{\overrightarrow{0}}{\circ}$ & $\begin{array}{l}8 \\
0\end{array}$ & 菅 & 8 & $\stackrel{d}{\circ}$ & ठ̊. & $\stackrel{\overrightarrow{0}}{0}$ & $\stackrel{8}{\circ}$ \\
\hline & $\therefore$ & $\begin{array}{l}\stackrel{n}{0} \\
\stackrel{0}{1}\end{array}$ & $\begin{array}{l}8 \\
: 0 \\
i\end{array}$ & 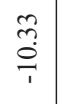 & $\begin{array}{l}\stackrel{q}{0} \\
\stackrel{+}{1}\end{array}$ & $\begin{array}{l}0 \\
0 \\
0 \\
0 \\
1\end{array}$ & $\begin{array}{l}\hat{f} \\
\stackrel{0}{0}\end{array}$ & $\begin{array}{l}\infty \\
0 \\
0 \\
0 \\
1\end{array}$ & $\begin{array}{l}8 \\
\stackrel{0}{0} \\
1\end{array}$ & $\stackrel{\hat{\sigma}}{\hat{i}}$ & $\begin{array}{l}0 \\
\stackrel{0}{+} \\
1\end{array}$ & $\begin{array}{c}0 \\
\stackrel{0}{0} \\
\stackrel{0}{1}\end{array}$ & $\begin{array}{l}0 \\
0 \\
0\end{array}$ & $\hat{\vec{i}}$ & \begin{tabular}{|l|} 
\\
0 \\
\\
1
\end{tabular} & $\mid \begin{array}{c}0 \\
\hat{0} \\
\stackrel{0}{1}\end{array}$ & $\begin{array}{l}g \\
\stackrel{g}{0} \\
\stackrel{+}{1}\end{array}$ & $\begin{array}{l}\vec{n} \\
0 \\
1\end{array}$ & $\mid \begin{array}{l}\hat{f} \\
\stackrel{0}{0} \\
\end{array}$ & 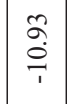 & $\begin{array}{l}\circ \\
\stackrel{2}{i}\end{array}$ & $\begin{array}{l}n \\
i \\
i\end{array}$ \\
\hline $\bar{z}$ & $P$ & & & & & & & & & & & $\begin{array}{l}0 \\
n \\
n\end{array}$ & 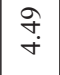 & & & $\begin{array}{c}f \\
\dot{i n}\end{array}$ & & & & & & \\
\hline $\begin{array}{l}\dot{0}^{+} \\
\dot{n}^{+}\end{array}$ & \multirow{8}{*}{ 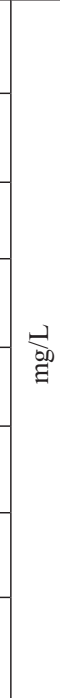 } & & & & & & & & & & & $\stackrel{g}{-}$ & $\begin{array}{l}0 \\
\vdots \\
0\end{array}$ & & $\underset{\beth}{\mathcal{I}}$ & $\stackrel{\vec{S}}{-}$ & & & & 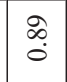 & & \\
\hline$\hat{z}^{-\infty}$ & & & & & & & & & & & & $\stackrel{\leftrightarrow}{\hookrightarrow}$ & $\stackrel{\infty}{\stackrel{-}{\longrightarrow}}$ & & $\stackrel{8}{:}$ & $\stackrel{g}{\rightarrow}$ & & & & $\underset{\sim}{\vec{F}}$ & & \\
\hline$\stackrel{+}{\tilde{z}}$ & & & & & & & & & & & & $\begin{array}{c}\tilde{c} \\
0\end{array}$ & $\begin{array}{c}\tilde{m} \\
\tilde{0}\end{array}$ & & స్ & $\vec{a}$ & & & & $\tilde{\overbrace{}}$ & & \\
\hline 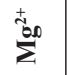 & & & & & & & & & & & & $\underset{\infty}{+}$ & in & & $\stackrel{\circ}{\stackrel{0}{r}}$ & $\begin{array}{l}n \\
0 \\
0\end{array}$ & & & & $\vec{n}$ & & \\
\hline $\bar{t}$ & & & & & & & & & & & & 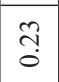 & $\begin{array}{l}0 \\
\text { in } \\
0\end{array}$ & & \begin{tabular}{|l|}
\multirow{y}{O}{} \\
\end{tabular} & গุ̣ & & & & $\overrightarrow{\tilde{y}}$ & & \\
\hline \pm & & & & & & & & & & & & oे & $\frac{\infty}{0}$ & & $\stackrel{\circ}{\circ}$ & \begin{tabular}{|l|} 
\\
\\
0
\end{tabular} & & & & $\begin{array}{l}\text { to } \\
0\end{array}$ & & \\
\hline 莡 & & & & & & & & & & & & i & f & & in & $\stackrel{\infty}{\sim}$ & & & & $\approx$ & & \\
\hline$\stackrel{g}{I}^{-m}$ & & & & & & & & & & & & $\stackrel{ \pm}{\Xi}$ & $\stackrel{8}{8}$ & & (ิ) & $\stackrel{\circ}{=}$ & & & & $\stackrel{ \pm}{0}$ & & \\
\hline$\hat{\theta}$ & $\mid \begin{array}{l}\overrightarrow{b 0} \\
\Xi\end{array}$ & & & & & & & & & & & $\begin{array}{l}n \\
\tilde{n} \\
n\end{array}$ & $\stackrel{\stackrel{\ominus}{\vec{\lambda}}}{\overrightarrow{\vec{v}}}$ & & $\mid \begin{array}{c}n \\
2 \\
m \\
\end{array}$ & $\vec{\Xi}$ & & & & 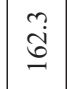 & & \\
\hline \pm & - & $\begin{array}{l}0 \\
\infty\end{array}$ & $\stackrel{\sim}{\infty}$ & $\stackrel{m}{\infty}$ & $\stackrel{m}{\infty}$ & $\underset{\infty}{+}$ & $\infty_{\infty}^{n}$ & $\underset{\infty}{+}$ & $\infty_{\infty}^{\infty}$ & $\underset{\infty}{+\infty}$ & $\hat{r}$ & $\stackrel{\partial}{r}$ & $\underset{\infty}{+}$ & $\begin{array}{l}n \\
\infty\end{array}$ & $\stackrel{2}{\cong}$ & $\vec{\infty}$ & $\stackrel{\infty}{\sim}$ & $\stackrel{\infty}{\sim}$ & $\begin{array}{l}0 \\
\infty\end{array}$ & $\begin{array}{l}0 \\
\infty\end{array}$ & $\stackrel{\circ}{\infty}$ & $\stackrel{m}{\infty}$ \\
\hline U. & 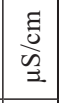 & $\tilde{\Omega}$ & $\stackrel{q}{I}$ & $\cong$ & $\underset{\infty}{\infty}$ & $\stackrel{\text { I }}{\mathcal{I}}$ & $\cong$ & $\tilde{m}$ & 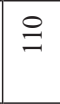 & $\cong$ & $\underline{6}$ & $\stackrel{\infty}{\sim}$ & $\underset{\sim}{\stackrel{\Delta}{*}}$ & $\overline{\vec{c}}$ & $\approx$ & $\cong$ & $\stackrel{ \pm}{I}$ & $\stackrel{\infty}{\simeq}$ & $\vec{\infty}$ & $\tilde{\Omega}$ & 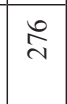 & $尺$ \\
\hline$F$ & 0 & $\stackrel{\circ}{\dot{b}}$ & $\dot{\vec{n}}$ & $\begin{array}{l}\infty \\
\dot{0}\end{array}$ & $\vec{i}$ & $\stackrel{?}{\sim}$ & 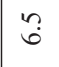 & $\stackrel{\infty}{\infty}$ & $\stackrel{9}{r}$ & $\vec{\infty}$ & $\begin{array}{l}\infty \\
\dot{\sim}\end{array}$ & $\overrightarrow{0}$ & $\begin{array}{l}0 \\
\infty\end{array}$ & $\stackrel{n}{a}$ & $\stackrel{?}{i}$ & $\stackrel{?}{?}$ & $\stackrel{2}{\sim}$ & $\infty$ & $\stackrel{\circ}{\infty}$ & $\stackrel{\Upsilon}{\nearrow}$ & $\begin{array}{l}n \\
\infty \\
\infty\end{array}$ & in \\
\hline 0 & $\stackrel{\infty}{\lrcorner}$ & & $a$ & 웅 & $\stackrel{\Omega}{\sim}$ & $\stackrel{2}{\gtrless}$ & 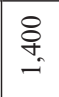 & 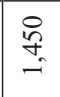 & & & & & & ¿ & \begin{tabular}{l}
8 \\
\hdashline \\
-1
\end{tabular} & $\begin{array}{l}0 \\
\text { in } \\
i \\
\end{array}$ & $\frac{8}{i}$ & \begin{tabular}{|l}
$\stackrel{\otimes}{\circ}$ \\
$\stackrel{8}{+}$ \\
$\sim$
\end{tabular} & 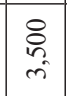 & & & \\
\hline \multicolumn{2}{|c|}{ 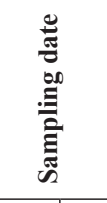 } & 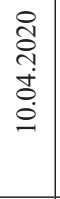 & 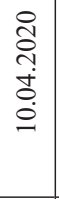 & $\begin{array}{l}\stackrel{0}{1} \\
\stackrel{0}{1} \\
+ \\
\dot{0} \\
\stackrel{0}{0}\end{array}$ & 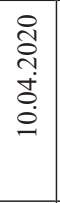 & 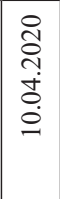 & 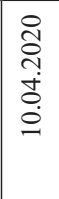 & 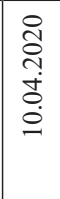 & 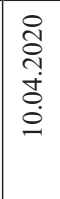 & 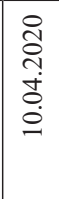 & 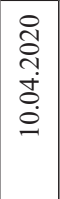 & 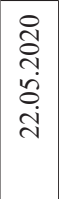 & 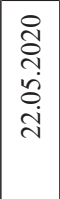 & 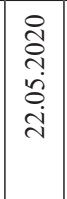 & 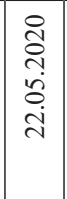 & 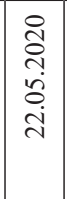 & 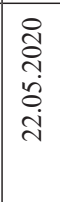 & 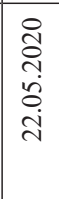 & 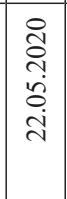 & 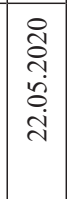 & 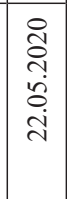 & $\begin{array}{l}\text { ते } \\
\text { ते } \\
\qquad \\
\text { ì } \\
\text { in }\end{array}$ \\
\hline $\mathbf{N}$ & $\mid \begin{array}{c}\overline{\overline{\dot{\phi}}} \\
\dot{\tilde{\sigma}} \\
\underline{\underline{\Xi}}\end{array}$ & $\begin{array}{l}\infty \\
\stackrel{i}{i} \\
\mathbb{i}\end{array}$ & 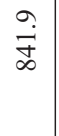 & $\vec{i}$ & $\stackrel{\dot{m}}{\circ}$ & $\frac{m}{m}$ & 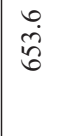 & $\begin{array}{l}\infty \\
\text { i } \\
\text { id }\end{array}$ & 옷 & $\begin{array}{l}0 \\
0 \\
0 \\
6\end{array}$ & $\begin{array}{l}\vec{t} \\
\stackrel{0}{-} \\
-1\end{array}$ & $\begin{array}{l}\infty \\
\stackrel{\sim}{\mathbb{Z}} \\
\end{array}$ & $\begin{array}{c}0 \\
\dot{i g} \\
\dot{\alpha}\end{array}$ & \begin{tabular}{|l|} 
\\
$\stackrel{\dot{\overrightarrow{+}}}{\infty}$ \\
\end{tabular} & $\frac{\hat{i}}{\mathrm{~s}}$ & $\begin{array}{c}0 \\
\dot{a} \\
i\end{array}$ & $\frac{m}{m}$ & $\begin{array}{l}0 \\
\tilde{b} \\
\hat{b}\end{array}$ & \begin{tabular}{|l|l}
$\infty$ \\
if \\
fo
\end{tabular} & $\begin{array}{c}\stackrel{\circ}{i} \\
\stackrel{i}{i}\end{array}$ & $\begin{array}{l}0 \\
\infty \\
\vdots \\
6\end{array}$ & 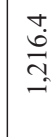 \\
\hline \multicolumn{2}{|c|}{$x$} & 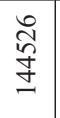 & $\begin{array}{l}\tilde{n} \\
\tilde{y} \\
\Xi\end{array}$ & 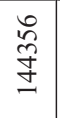 & 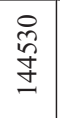 & $\begin{array}{l}\hat{0} \\
\stackrel{+}{ \pm} \\
\end{array}$ & 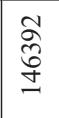 & $\begin{array}{l}\bar{\alpha} \\
\dot{\alpha} \\
\dot{0} \\
\end{array}$ & $\begin{array}{l}\tilde{\delta} \\
\tilde{8} \\
\dot{J} \\
\end{array}$ & $\begin{array}{l}n \\
2 \\
i g \\
\pm\end{array}$ & 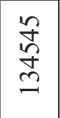 & $\begin{array}{l} \\
\text { D } \\
\text { 肙 } \\
\end{array}$ & 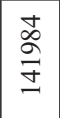 & \begin{tabular}{|c|}
$\tilde{n}$ \\
$\tilde{q}$ \\
$\dot{q}$
\end{tabular} & 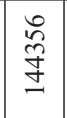 & 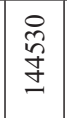 & $\begin{array}{l}\hat{0} \\
\text { 导 } \\
\end{array}$ & 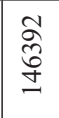 & \begin{tabular}{|l|}
$\overrightarrow{\widehat{D}}$ \\
$\dot{0}$ \\
$\dot{+}$
\end{tabular} & 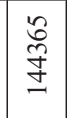 & 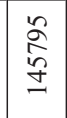 & 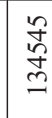 \\
\hline \multicolumn{2}{|c|}{$\lambda$} & 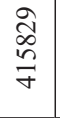 & $\begin{array}{l}\infty \\
\infty \\
\underset{\nabla}{\sigma}\end{array}$ & $\begin{array}{l}\frac{n}{\sim} \\
\stackrel{n}{7}\end{array}$ & $\begin{array}{l}\frac{J}{J} \\
\frac{n}{\sigma}\end{array}$ & $\begin{array}{l}\vec{a} \\
\hat{\sigma} \\
\overrightarrow{7}\end{array}$ & 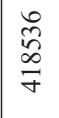 & $\frac{\vec{J}}{\stackrel{亠}{\vec{\sigma}}}$ & $\frac{ \pm}{a}$ & $\begin{array}{l}\tilde{n} \\
\frac{n}{\sigma} \\
F\end{array}$ & 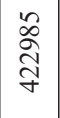 & $\begin{array}{c}\stackrel{\infty}{\infty} \\
\stackrel{n}{\sigma} \\
\forall\end{array}$ & $\begin{array}{l}\hat{o} \\
\mathfrak{q} \\
\mathfrak{z} \\
\end{array}$ & \begin{tabular}{|l|}
$\infty$ \\
$\stackrel{\infty}{\forall}$ \\
$\vec{f}$
\end{tabular} & $\begin{array}{l}\frac{7}{7} \\
\hat{n} \\
\forall \\
\end{array}$ & $\begin{array}{c}\frac{J}{7} \\
i n \\
\vec{f} \\
\end{array}$ & $\begin{array}{l}\vec{\sigma} \\
\hat{n} \\
\vec{\gamma}\end{array}$ & \begin{tabular}{|l}
$\infty$ \\
$\infty$ \\
$\infty$ \\
$\varnothing$ \\
$\forall$ \\
\end{tabular} & \begin{tabular}{|l|}
$\vec{J}$ \\
$\partial$ \\
$\partial$ \\
$\vec{\sigma}$
\end{tabular} & 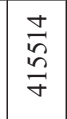 & $\begin{array}{l}\tilde{n} \\
\infty \\
\vec{\gamma}\end{array}$ & 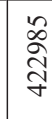 \\
\hline \multicolumn{2}{|c|}{$\sum_{z}^{\circ}$} & $\begin{array}{l}\text { 总 } \\
\text { n }\end{array}$ & $\stackrel{\vec{\nu}}{\Omega}$ & $\overrightarrow{\vec{\Delta}}$ & $\stackrel{\overrightarrow{\vec{\nu}}}{\vec{\alpha}}$ & $\stackrel{\breve{ٌ}}{\check{\sim}}$ & $\stackrel{\vec{\Delta}}{\approx}$ & $\stackrel{\vec{\Xi}}{\approx}$ & $\stackrel{\grave{n}}{\sim}$ & 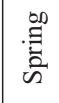 & $\begin{array}{l}\text { 总 } \\
\text { 竞 }\end{array}$ & 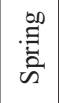 & 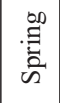 & 离 & 产 & 产 & $\stackrel{\overrightarrow{3}}{\sim}$ & $\overline{\vec{\nu}}$ & 离 & $\stackrel{\vec{\Xi}}{2}$ & 曾 & 量 \\
\hline \multicolumn{2}{|c|}{ 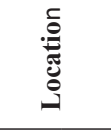 } & $\frac{m}{\vec{N}}$ & 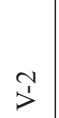 & $\stackrel{r}{i}$ & $\stackrel{\varphi}{~}$ & $\stackrel{+}{>}$ & $\bar{I}$ & $\stackrel{n}{>}$ & $\vec{a}$ & $\overrightarrow{\dot{n}}$ & $\overrightarrow{\bar{n}}$ & $\frac{m}{\frac{1}{N}}$ & 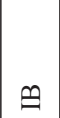 & $\stackrel{\sim}{>}$ & $\stackrel{m}{>}$ & 心 & $\underset{⿱}{>}$ & $\vec{I}$ & $\begin{array}{l}n \\
i\end{array}$ & $\vec{a}$ & $\overrightarrow{\dot{n}}$ & $\overline{\dot{n}}$ \\
\hline
\end{tabular}



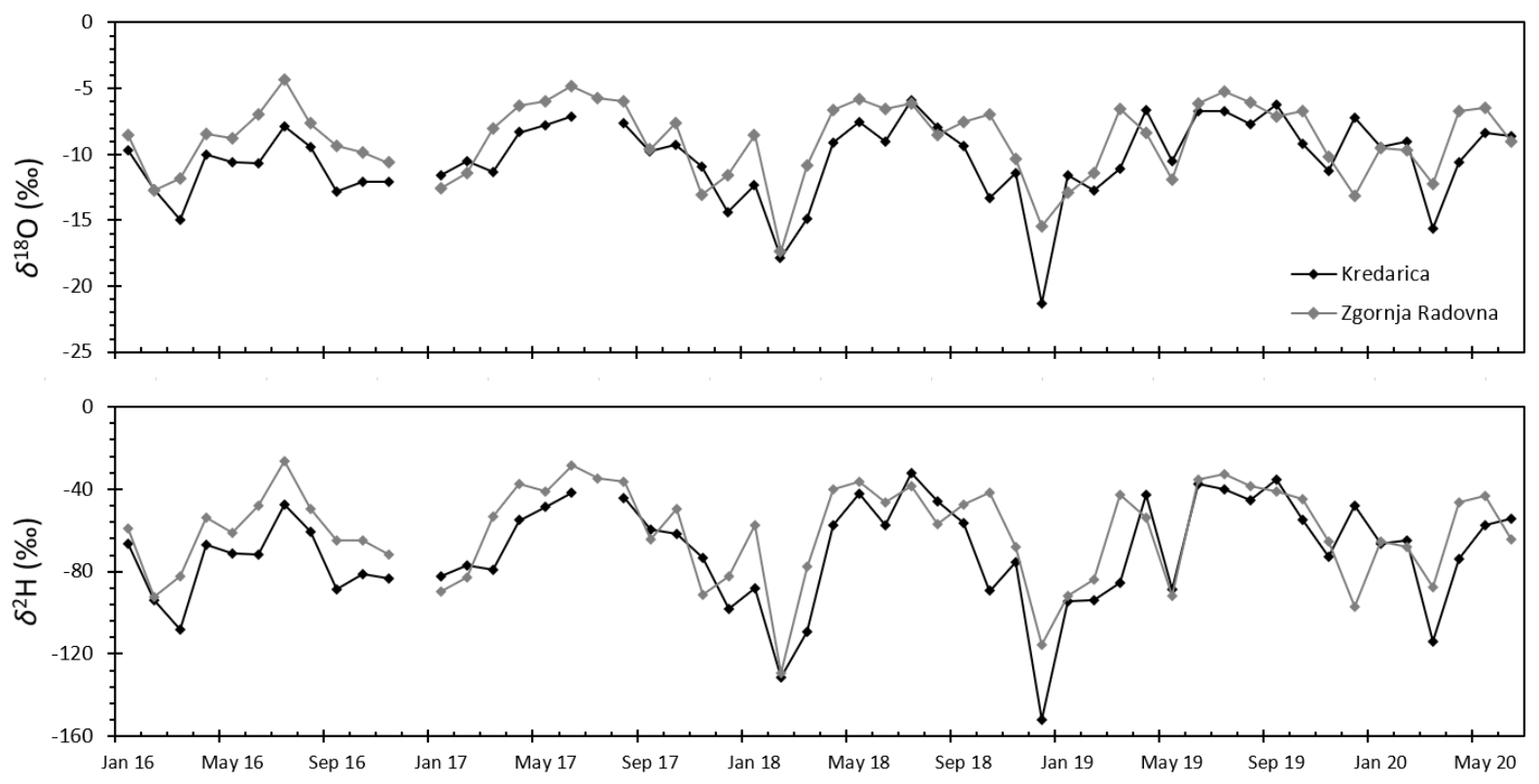

Fig. 6. Isotopic composition of precipitation at the Zgornja Radovna and Kredarica meteorological stations for the period 2016-2020.

\section{Stable isotopes}

\section{$\delta^{18} \mathrm{O}$ and $\delta^{2} \mathrm{H}$ in precipitation}

The lowest isotopic precipitation values can be observed at the Kredarica meteorological station. The average unweighted values for the observation period $2016-2020$ are $-10.4 \%$, and $-70.5 \%$ for $\delta^{18} \mathrm{O}$ and $\delta^{2} \mathrm{H}$, respectively. The lowest value was determined in December 2018 and corresponds to the snow precipitation sample. At the Zgornja Radovna meteorological station the average unweighted values for the observation period 2016-2020 are $-8.9 \%$ and $-60.7 \%$ for $\delta^{18} \mathrm{O}$ and $\delta^{2} \mathrm{H}$, respectively. The average isotopic composition of snow at the Kredarica meteorological station was determined to be $-13.5 \%$ for $\delta^{18} \mathrm{O}$ and $-98.1 \%$ for $\delta^{2} \mathrm{H}$. Slightly more positive values were observed at Zgornja Radovna: $-12.1 \%$ for $\delta^{18} \mathrm{O}$, and $-87.1 \%$ for $\delta^{2} \mathrm{H}$.

The altitude effect was calculated for the two selected meteorological stations - Kredarica and Zgornja Radovna - separately, for total precipitation and for months when snow prevails in the monthly composite sample. These were selected based on a comparison of stable isotope data (Fig. 6) and meteorological parameters (days with snow/rain, amount of precipitation, snow cover thickness, etc.). It was estimated that the altitude effect in precipitation is $-0.8 \%{ }^{18} \mathrm{O} / \mathrm{km}$. This value is in good agreement with the estimated altitude effect based on spring water $\delta^{18} \mathrm{O}$ values $\left(-1.1 \% \delta^{18} \mathrm{O} / \mathrm{km}\right)$ in the Radovna River valley in NW Slovenia (Torkar et al., 2016) and (-1 \%o $\delta^{18} \mathrm{O} / \mathrm{km}$ ) in Lake Bled and surroundings (Serianz et al., 2020b).

\section{Isotopic composition of water samples}

Values for $\delta^{18} \mathrm{O}, \delta^{2} \mathrm{H}$ and ${ }^{3} \mathrm{H}$ are presented in Table 1. Values for $\delta^{18} \mathrm{O}$ in all water samples are between $-10.9 \%$ and $-9.6 \%$. In general, $\delta^{18} \mathrm{O}$ values were lower in the second sampling campaign (Fig. 8). Excluding location IB, the differences between both campaigns range from $0.03 \%$ at $\mathrm{S}-1$ up to $0.5 \%$ at MS-1. The first sampling at MS-1 was performed when there was still approx. $50 \mathrm{~cm}$ of snowpack in the recharge area, while during the second sampling the snowpack had already melted. The values for $\delta^{2} \mathrm{H}$ in all water samples are between $-73.3 \%$ and $-63.1 \%$. $\delta^{2} \mathrm{H}$ values are also lower in the second sampling campaign. Excluding location IB, the differences between both campaigns range from $0.3 \%$ at $\mathrm{V}-5$ up to $3.5 \%$ at MS-1. The results of $\delta^{18} \mathrm{O}$ and $\delta^{2} \mathrm{H}$ measurements in groundwater and surface

Table 2: Altitude effect for snow and total precipitation calculated based on samples from Kredarica and Zgornja Radovna meteorological stations.

\begin{tabular}{lll} 
Parameter & Equation & Slope \%o/ $\mathbf{~ k m}$ \\
\hline$\delta^{18} \mathrm{O}_{\text {total }}$ & $\mathrm{Y}=-0.0008 \mathrm{x}-8.272$ & -0.8 \\
$\delta^{18} \mathrm{O}_{\text {snow }}$ & $\mathrm{Y}=-0.0008 \mathrm{x}-11.561$ & -0.8 \\
$\delta^{2} \mathrm{H}_{\text {total }}$ & $\mathrm{Y}=-0.0056 \mathrm{x}-56.426$ & -5.6 \\
$\delta^{2} \mathrm{H}_{\text {snow }}$ & $\mathrm{Y}=-0.0062 \mathrm{x}-82.379$ & -6.2 \\
\hline
\end{tabular}



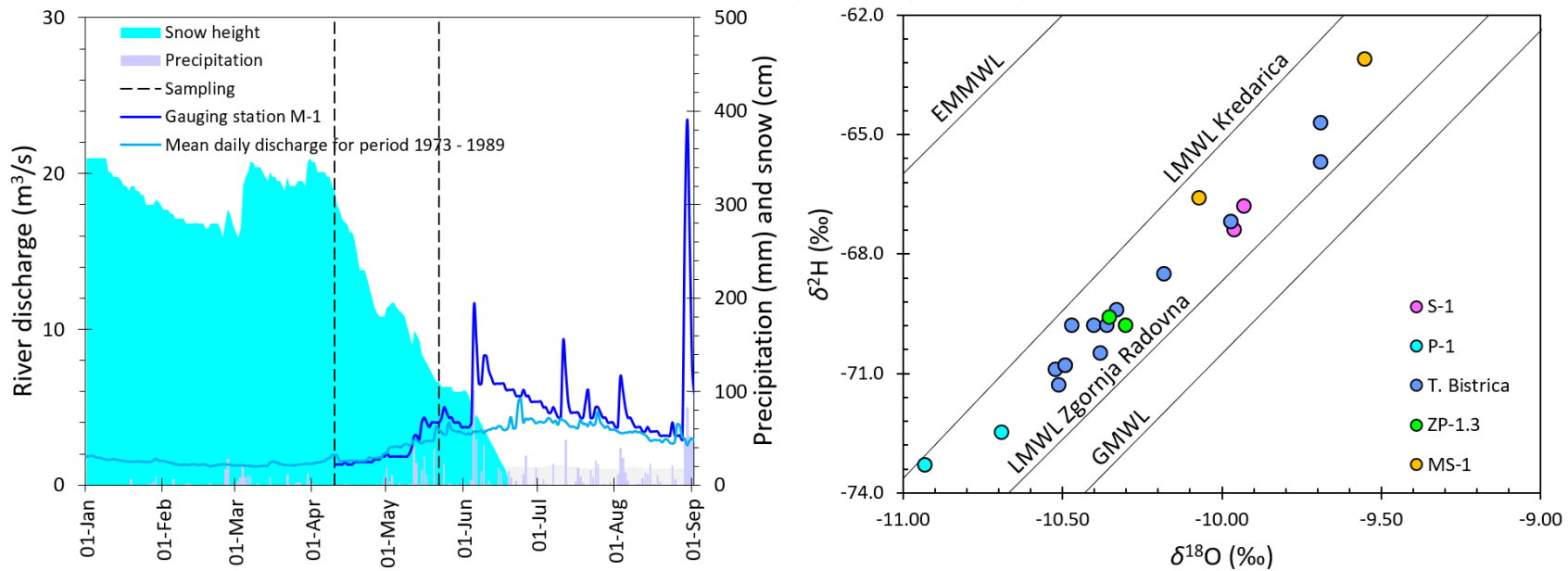

Fig. 7: Meteorological parameters during sampling (left) and the results of stable isotope analysis, together with Global Meteoric Water Line (GMWL) and East Mediterranean Meteoric Water Line (EMMWL)(right).

water are shown in Figure 7b, as compared to the global meteoric line (GMWL) (Craig, 1961). The results show that all water samples are located between LMWLs for Kredarica and Zgornja Radovna.

The isotopic composition also allows us to estimate the mean recharge altitude of the groundwater, namely in conditions where we have reference locations with a known isotopic composition and a correspondingly small recharge area, for which we can estimate the average altitude. As follows from previous research in a wider area (Torkar, 2016; Serianz et al., 2020b), $\delta^{18} \mathrm{O}$ is particularly suitable for a relevant assessment, and $\delta^{2} \mathrm{H}$ yields inapplicable results (indicates higher altitudes than in nature). In the given case, we used the spring Mrzli studenec (MS-1) in Poklju$\mathrm{ka}$ (approx. $12 \mathrm{~km}$ air distance from the Triglavska Bistrica) and the spring "Na Skedenjcih" (S-1, Fig. 1) as the reference location. Stable isotope analysis has been performed on the MS-1 spring in the past, as this spring, according to the data available so far from the wider area, represents one of the highest-lying springs with a constant flow and a small drainage area (Serianz et al., 2020b).

Based on the isotopic composition it is also possible to estimate the mean recharge area of a given water sample using the simple linear relationship between the representative water sample with known recharge altitude and isotopic composition. In this case two springs were selected, MS-1 and S-1, based on the assumption that the isotopic signature of spring water is due to the small catchment area equal to the isotopic signature of precipitation at the corresponding altitude. The results, however, suggest only spring MS-1 is appropriate for such hypothesis, while spring S-1 was not appropriate for consideration. Therefore, an alternative approach was used, accounting for average $\delta^{18} \mathrm{O}$ from both sampling campaigns and a calculated precipitation altitude effect of $-0.8 \%{ }^{18} \mathrm{O} / \mathrm{km}$. The results show that the Triglavska Bistrica spring area
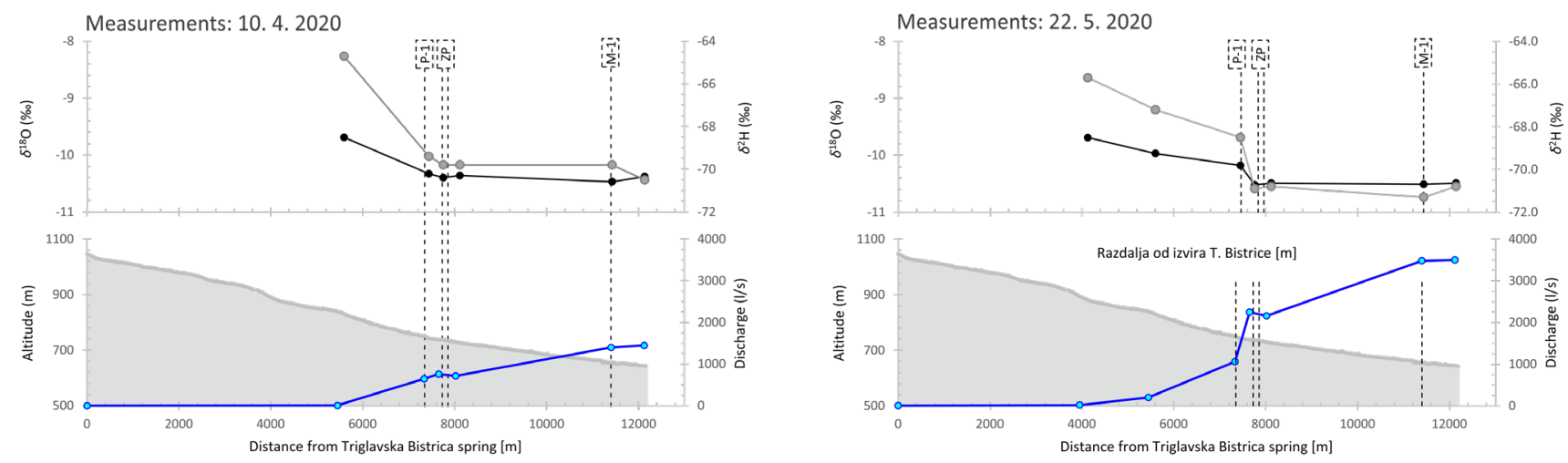

$\longrightarrow$ river bed profile $\multimap$ discharge $\rightarrow \delta^{18} \mathrm{O} \longrightarrow \delta^{2} \mathrm{H}$

Fig. 8. Graphical analysis of stable isotope analysis. 


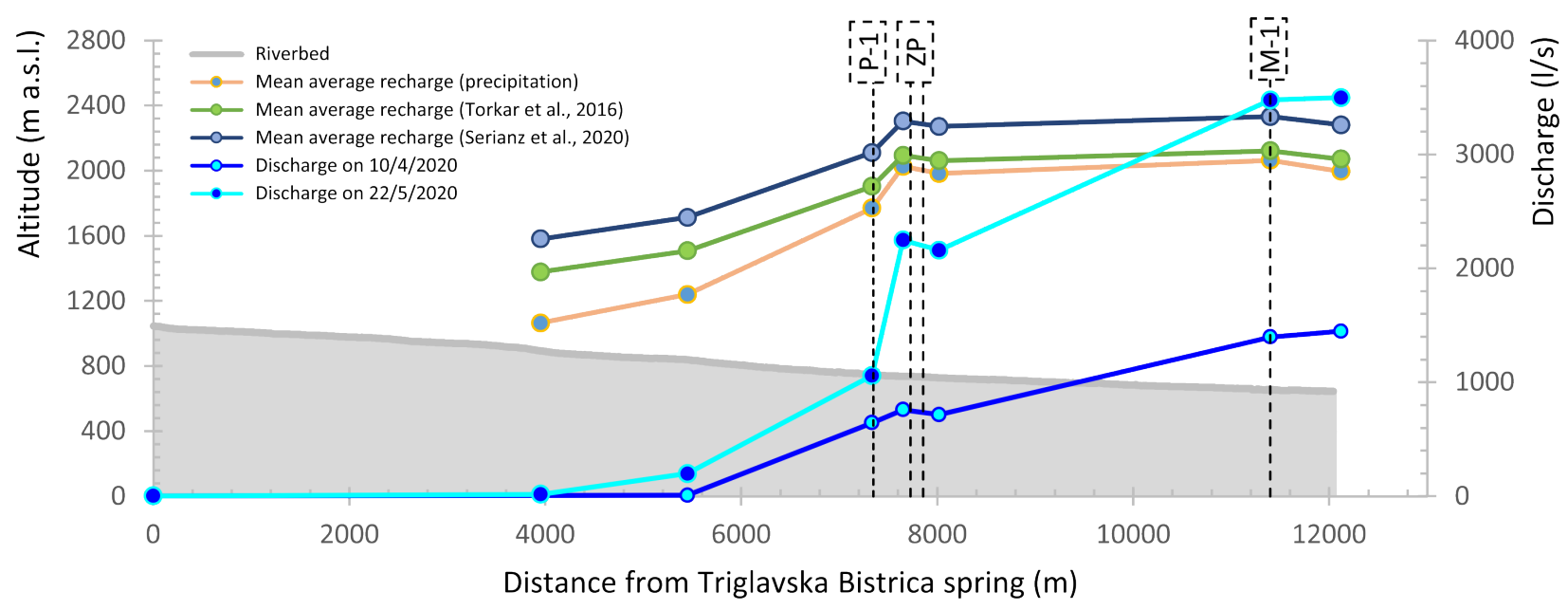

Fig. 9. Hydrogeological parameters of Triglavska Bistrica.

is of local recharge component, while with the distance downstream the regional groundwater recharge component is much more significant (Fig. 9). At the sampling location V-5, which is approx. $300 \mathrm{~m}$ upstream from the Sava Dolinka confluence, the average recharge altitude is estimated at 1,996 $\mathrm{m}$ a.s.l. (Fig. 9). Mean average recharge is even higher in the case of linear models from literature (Torkar et al., 2016; Serianz et al., 2020b). The calculated mean recharge altitude of the Triglavska Bistrica at its discharge into the Sava Dolinka was evaluated based on a Digital elevation model and was determined as approx. $1,500 \mathrm{~m}$ a.s.l.

All water samples analysed for tritium activity concentration can be classified as recent waters (Mezga, 2014). According to the ${ }^{3} \mathrm{H}$ results in the groundwater in the Peričnik catchment (3.5 TU), it is evident that the lower tritium activity concentration is due to the lower than expected values of tritium, which are characteristic for snow precipitation (Vreča et al., 2013). The recharge area of the Peričnik stream is represented by a high-altitude karstic-fissured aquifer, where dolomite predominates over limestone. As a result, such an aquifer has a higher storage capacity, which is reflected in a longer retention time. Sampling points at Triglavska Bistrica BG and IB, which are located upstream from the Peričnik stream and recharge from both an intermediate flow component in the karstic-fissured aquifer and local flow components in Quaternary aquifers, show slightly higher tritium activities (5.4 TU and 4.5 TU, respectively). For a reliable estimation of retention times, systematic long-term observation of the geochemical and isotope characteristics of all water components (i.e. precipitation, snow, surface- and ground-water) is crucial.

\section{Conclusions}

The hydrogeochemistry of the Triglavska Bistrica is determined by the prevalence of $\mathrm{Ca}^{2+}$ and $\mathrm{Mg}^{2+}$ cations and $\mathrm{HCO}_{3}^{-}$anions. The hydrogeochemical water types are $\mathrm{Ca}-\mathrm{Mg}-\mathrm{HCO}_{3}$ and $\mathrm{Ca}-$ $\mathrm{HCO}_{3}$, suggesting dolomite and limestone in the recharge area. The spatial variations in water carbonate chemistry along the valley are attributed to different lithologies. That means that the recharge area of the Triglavska Bistrica spring is an aquifer or aquifer system dominated by limestone, while other waters downstream are characterized by the fact that they are mainly fed by aquifers dominated by dolomite over limestone. Analysis of the $\mathrm{pH}$ and major ions indicate that the water is alkaline and that carbonate weathering as a process dominates in the recharge area. Other major ions are present in low concentrations and within natural background levels.

The $\delta^{18} \mathrm{O}$ and $\delta^{2} \mathrm{H}$ values decrease along the Triglavska Bistrica valley, which means that the mean altitude of the recharge area increases downstream. At the spring, where lower altitude recharge prevails, the groundwater is enriched with ${ }^{18} \mathrm{O}$, while at the downstream locations groundwater becomes increasingly depleted in ${ }^{18} \mathrm{O}$ due to the increasing impact of snow melt water infiltrated at higher altitudes. The mean recharge altitude area of the Triglavska Bistrica River was estimated at approx. 1,996 m a.s.l. at sampling point V-5, located approx. $12 \mathrm{~km}$ downstream from the spring. The concentrations of tritium activity in groundwater correspond to natural processes related to precipitation. However, a more precise analysis of the residence time would require a systematic series of measurements over many years. 
The results of this study provide important and useful new information about the hydrogeological characteristics of the recharge area of the Triglavska Bistrica, allowing researchers to compare and define groundwater recharge areas in similar hydrogeological systems. We expect the results of this study could also be used as a basis for different hydrological and hydrogeological studies, where water sources need to be investigated. The Triglavska Bistrica catchment is highly important as a source of drinking water, as it also represents the recharge of the Peričnik spring, which itself is an important water resource for part of the municipality of Jesenice. Therefore, it is very important to understand the dynamics of the different flow components in the studied aquifer system. In view of constant climatic changes, especially increasing air temperature, increasingly shorter snow periods of snow cover, and changing water infiltration, this important resource should be carefully monitored now and in the future.

\section{Acknowledgments}

The authors would like to thank the Municipality of Jesenice for financial support. Part of this research was also funded by the Slovenian Research Agency (ARRS) in the frame of the young researcher programme and research programmes "Groundwater and Geochemistry" (No. P1-0020) of the Geological Survey of Slovenia and "Cycling of substances in the environment, mass balances, modelling of environmental processes, and risk assessment" (P1-0143) of the Jožef Stefan Institute.

\section{References}

Appelo, C A J. \& Postma, D. 2005: Geochemistry, groundwater and pollution. 2nd edition. Rotterdam, Balkema.

Avak, H. \& Brand, W.A. 1995: The finning MAT HDO-equilibration-A fully automated $\mathrm{H}_{2} \mathrm{O}$ / gas phase equilibration system for hydrogen and oxygen isotope analyses. Thermo Electron. Corp. Appl. News, 11: 1-13.

Brenčič, M. \& Poltnig, W. 2008: Groundwater Karavanke: hidden wealth. Ljubljana and Graz: Geological Survey of Slovenia \& Joanneum Research Forschungsgesellschaft, Report.

Brenčič, M. \& Vreča, P. 2016: Hydrogeological and isotope mapping of the karstic River Savica in NW Slovenia. Environ. Earth Sci, 75(65). https://doi.org/10.1007/s12665-016-5479-7
Carey, S. K. \& Quinton, W. L. 2005: Evaluating runoff generation during summer using hydrometric, stable isotope and hydrochemical methods in a discontinuous permafrost alpine catchment. Hydrological Processes: An International Journal, 19/1: 95-114.

Cerar, S., Mezga, K., Žibret, G., Urbanc, J. \& Komac, M. 2018: Comparison of prediction methods for oxygen-18 isotope composition in shallow groundwater. Science of the Total Environment, 631-632: 358-368. https://doi. org/10.1016/j.scitotenv.2018.03.033

Clark, I. \& Fritz, P. 1997: Environmental Isotopes in Hydrogeology. CRC Press: New York: 328 p.

Coplen, T., Wildman, J. \& Chen, J. 1991: Improvements in the gaseous hydrogen-water equilibration technique for hydrogen isotope ratio analysis. Analytical Chemistry, 63: 910-912.

Craig, H. 1961: Isotope variations in meteoric waters. Science, 133/3465: 1702-1703.

Dansgaard, W. 1964: Stable isotopes in precipitation. Tellus, 16: 436-468.

Epstein, S. \& Mayeda, T. 1953: Variations of ${ }^{18} \mathrm{O}$ content of waters from natural sources. Geochimica et Cosmochimica Acta, 4: 213-224.

Gat, J.R. \& Carmi, I. 1970: Evolution of the isotopic composition of atmospheric waters in the Mediterranean Sea area. Journal of Geophysical Research, 75: 3039-3048. https:// doi.org/10.1029/JC075i015p03039

Gonfiantini, R., Roche, M.-A., Olivry, J.-C., Fontes, J.-C. \& Zuppi, G.M. 2001: The altitude effect on the isotopic composition of tropical rains. Chemical Geology, 181: 147-167.

Hanna instruments. Instruction manual: HI98194, HI98195, HI98196 Multiparameter Meters $\mathrm{pH} / \mathrm{mV}$, ORP, EC, TDS, Resistivity, Salinity, Seawater, Dissolved Oxygen, Atmospheric Pressure and Temperature, 2020a. (16. 7. 2020).

Horvatinčić, N., Krajcar Bronić, I., Barešić, J., Obelić, B. \& Vidič, S. 2005: Tritium and stable isotope distribution in the atmosphere at the coastal region of Croatia. In: Final report of a coordinated research project 2000-2004 (IAEA-TECDOC Series No. 1453) - Isotopic Composition of Precipitation in the Mediterranean Basin in Relation to Air Circulation Patterns and Climate). Vienna (AU) IAEA, 37-50.

Hrvatin, M. 1998: Pretočni režimi v Sloveniji. Geografski zbornik, 38: 59-87. 
Nadbath, M. 2014: Meteorološka postaja Kredarica. Naše okolje. Internet: https://meteo.arso.gov.si/uploads/probase/www/climate/text/sl/stations/kredarica.pdf (15.9.2021)

Jurkovšek, B. 1987: Osnovna geološka karta SFRJ, 1:100.000. Tolmač listov Beljak (Villach) in Ponteba: L 33-51, L 33-52. Zvezni geološki zavod. Beograd: 58 p.

Kanduč, T., Mori, N., Kocman, D., Stibilj, V. \& Grassa, F. 2012: Hydrogeochemistry of Alpine springs from North Slovenia: insights from stable isotopes. Chemical Geology, 300-301: 40-54.

Katz, B.G. 1998: Using $\delta^{18} \mathrm{O}$ and $\delta \mathrm{D}$ to Quantify Ground-Water / Surface-Water Interactions in Karst Systems of Florida. In: National Water Quality Monitoring Council Conference: Critical Foundations to Protect Our Waters. Reno, Navada. U.S. Environmental Protection Agency, Washington D.C.

Kern, Z., Hatvani, I.G., Czuppon, G., Fórizs, I., Erdélyi, D., Kanduč, T., Palcsu, L. \& Vreča, P. 2020: Isotopic 'Altitude' and 'Continental' Effects in Modern Precipitation across the Adriatic-Pannonian Region. Water, 12/6:1797. https://doi.org/10.3390/w12061797

Kralik, M., Papesch, W. \& Stichler, W. 2003: Austrian Network of Isotopes in Precipitation (ANIP): Quality assurance and climatological phenomenon in one of the oldest and densest networks in the world. In: IAEA. Isotope Hydrology and Integrated Water Resources Management. Proceedings; 2003 May 19-13; Vienna (AU): International Atomic Energy Agency and the International Association of Hydrogeologists in cooperation with the International Association of Hydrological Sciences, 146-149.

Longinelli, A. \& Selmo, E. 2003: Isotopic composition of precipitation in Italy: a first overall map. Journal of Hydrology, 270/1-2: 75-88.

Mayo, L. \& Loucks, M.D. 1995: Solute and isotopic geochemistry and ground water flow in the central Wasatch Range, Utah. Journal of Hydrology, 172: 31-59.

Mezga, K., Urbanc, J. \& Cerar, S. 2013: The isotope altitude effect reflected in groundwater: a case study from Slovenia. Isotopes in environmental and health studies, 50/1: 33-51. https://doi.org/10.1080/10256016.2013.826213

Mezga, K. 2014: Natural hydrochemical background and dynamics of groundwater in Slovenia: doctoral dissertation. Nova Gorica: $226 \mathrm{p}$.

Piper, A.M. 1944: A graphic procedure in the geochemical interpretation of water-analyses.
Eos, Transactions American Geophysical Union, 25/6: 914-928.

Poage, M.A. \& Chamberlain, C.P. 2001: Empirical Relationships Between Elevation and the Stable Isotope Composition of Precipitation and Surface Waters: Considerations for Studies of Paleoelevation Change. American Journal of Science, 301: 1-15.

Serianz, L. 2016: Tri-dimensional Model of the Radovna Glacier from the Last Glacial Period. Geologija, 59/2: 193-204. https://doi. org/10.5474/geologija.2016.011

Serianz, L., Cerar \& S., Šraj, M. 2020a. Hydrogeochemical characterization and determination of natural background levels (NBL) in groundwater within the main lithological units in Slovenia. Environmental Earth Sciences, 79: 373 https://doi.org/10.1007/ s12665-020-09112-1

Serianz, L., Rman, N. \& Brenčič, M. 2020b: Hydrogeochemical Characterization of a Warm Spring System in a Carbonate Mountain Range of the Eastern Julian Alps, Slovenia. Water, 127/5: 1427. https://doi. org/10.3390/w12051427

Shamsi, A., Karami, G. H., Hunkeler, D. \& Taheri, A. 2019: Isotopic and hydrogeochemical evaluation of springs discharging from high-elevation karst aquifers in Lar National Park, northern Iran. Hydrogeology Journal, 27/2: 655-667. https://doi.org/10.1007/ s10040-018-1873-4

Smolar-Žvanut, N., Mikoš, M. \& Breznik, B. 2005: The impact of the dam in the Bistrica River on the aquatic ecosystem. Acta Hydrotechnica, 23/39: 99-115.

SIST ISO 5667-03:1996. Water quality, sampling - part 3: instructions for storage and handling of samples.

SIST ISO 5667-11:1996. Water quality, sampling - part 11: guidance on sampling of groundwater, 1-10.

SIST ISO 5667-6:1996. Water quality, sampling - part 6: guidance on sampling of rivers and water courses.

Thiébauda, E., Dzikowski, M., Gasquet, D. \& Renac, D. 2010: Reconstruction of groundwater flows and chemical water evolution in an amagmatic hydrothermal system ( $\mathrm{La}$ Léchère, French Alps). Journal of Hydrology, 381/3-4, 15, 189-202.

Torkar, A., Brenčič, M. \& Vreča, P. 2016: Chemical and isotopic characteristics of groundwater-dominated Radovna River (NW Slovenia). Environ. Earth Sci, 75: 1296-1314. 
Vreča, P. \& Malenšek, N. 2016: Slovenian Network of Isotopes in Precipitation (SLONIP) - a review of activities in the period 1981-2015 = Slovenska mreža opazovanj izotopske sestave padavin (SLONIP) - pregled aktivnosti v obdobju 1981-2015. Geologija, 59: 67-83. https:// doi.org/10.5474/geologija.2016.004

Vreča, P., Krajcar Bronić, I., Horvatinčić, N. \& Barešić, J. 2006: Isotopic characteristics of precipitation in Slovenia and Croatia: comparison of continental and maritime stations. Journal of Hydrology 330/3-4: 457-469. https://doi.org/10.1016/j.jhydrol.2006.04.005

Vreča, P., Krajcar Bronič, I., Leis, A. \& Brenčič, M. 2008: Isotopic composition of precipitation in Ljubljana (Slovenia). Geologija, 51/2:169180. https://doi.org/10.5474/geologija.2008.018

Vreča, P., Brenčič, M., Sinjur, I., Vertačnik, G., Volk, B. M., Ortar, J., Torkar, A., Stibilj, V. \&
Pavšek, M. 2013: Izotopska sestava padavin in snega na območju Julijskih Alp in Karavank. Raziskave s področja geodezije in geofizike 2012: 17-25.

Vreča, P., Krajcar Bronič, I., Leis, A. \& Demšar, M. 2014: Isotopic composition of precipitation at the station Ljubljana (Reaktor), Slovenia - period 2007-2010. Geologija, 57/2: 217-230. https://doi.org/10.5474/geologija.2014.019

Internet sources:

Internet 1: Archive of weather observations. Slovenian Environment Agency. Internet: http://meteo.arso.gov.si (1. 3. 2021).

Internet 2: Archive of hydrological data. Slovenian Environment Agency. Internet: http://vode.arso.gov.si/hidarhiv (5. 2. 2021).

Internet 3: https://jeko.si/vodovod-pericnik-2 (1. 9. 2021)

Internet 4: https://slonip.ijs.si/ (7. 8. 2021) 